\title{
Microalgal Biomass as a Biorefinery Platform for Biobutanol and Biodiesel Production
}

DOI:

10.1016/j.bej.2019.107396

\section{Document Version}

Accepted author manuscript

Link to publication record in Manchester Research Explorer

\section{Citation for published version (APA):}

Figueroa Torres, G., Wan Mahmood, W. M. A. B., Pittman, J., \& Theodoropoulos, C. (2020). Microalgal Biomass as a Biorefinery Platform for Biobutanol and Biodiesel Production. Biochemical Engineering Journal, 153, [107396]. https://doi.org/10.1016/j.bej.2019.107396

\section{Published in:}

Biochemical Engineering Journal

\section{Citing this paper}

Please note that where the full-text provided on Manchester Research Explorer is the Author Accepted Manuscript or Proof version this may differ from the final Published version. If citing, it is advised that you check and use the publisher's definitive version.

\section{General rights}

Copyright and moral rights for the publications made accessible in the Research Explorer are retained by the authors and/or other copyright owners and it is a condition of accessing publications that users recognise and abide by the legal requirements associated with these rights.

\section{Takedown policy}

If you believe that this document breaches copyright please refer to the University of Manchester's Takedown Procedures [http://man.ac.uk/04Y6Bo] or contact uml.scholarlycommunications@manchester.ac.uk providing relevant details, so we can investigate your claim.

\section{OPEN ACCESS}




\title{
Microalgal Biomass as a Biorefinery Platform for Biobutanol and Biodiesel Production
}

\author{
Gonzalo M. Figueroa-Torres ${ }^{a}$, Wan M. Asyraf Wan Mahmood ${ }^{a}$, Jon K. Pittman ${ }^{\text {, }}$ \\ Constantinos Theodoropoulos ${ }^{\mathrm{a}, *}$ \\ ${ }^{a}$ Department of Chemical Engineering and Analytical Science, Biochemical and Bioprocess Engineering \\ Group, The University of Manchester, Manchester, M13 9PL \\ ${ }^{b}$ Department of Earth and Environmental Sciences, The University of Manchester, Manchester, M13 9PL
}

* Corresponding author:

Prof. Constantinos Theodoropoulos

Postal address: Department of Chemical Engineering and Analytical Science, The University of Manchester, The Mill, Sackville Street, Manchester, M13 9PL, U.K.

E-mail: k.theodoropoulos@manchester.ac.uk 


\begin{abstract}
Microalgal biorefineries have recently emerged as a potentially economically viable option for the co-production of value-added products and fuels, such as biodiesel (via the transesterification of lipids) and biobutanol (via the fermentation of carbohydrates). Whilst microalgal biodiesel has been studied extensively, microalgal biobutanol has received less attention due to the low product yields of the biochemical process from which biobutanol is obtained: the Acetone-Butanol-Ethanol (ABE) fermentation. In this work, we evaluate the potential of a microalgae-based biorefinery by: i) quantifying biobutanol production via $\mathrm{ABE}$ fermentation of microalgae (raw and hydrolysate form) using a medium optimised via surface response analysis (SRA) methodology; ii) quantifying biodiesel (fatty acid methyl esthers, FAMEs) production via transesterification of microalgae (raw, hydrolysed, and fermented form). Using SRA-optimised medium, butanol fermentation yields of $10.31 \%\left(\mathrm{~g} \mathrm{~g}^{-1} \mathrm{cdw}\right)$ and $10.07 \%\left(\mathrm{~g} \mathrm{~g}^{-1}\right.$ glucose $)$ were attained by microalgae in raw and hydrolysate form, respectively. Meanwhile, the raw, hydrolysed, and fermented microalgae yielded up to 0.92 $\%, 3.82 \%$ and $3.29 \%\left(\mathrm{~g} \mathrm{~g}^{-1} \mathrm{cdw}\right)$ biodiesel, respectively. Results highlight the importance of pretreatment methods and further support the development of microalgal biorefineries for dual biofuel production.
\end{abstract}

Keywords: biobutanol, biodiesel, biorefineries, fermentation, microalgae. 


\section{Introduction.}

Microalgal biofuels, so-called third generation biofuels, have been praised due to their potential to become sustainable replacements for fossil-based fuels which are large contributors to greenhouse gas emissions. The production of microalgal biofuels is estimated to require less land, water, and fertiliser usage than first generation food-based biofuels (e.g. ethanol from corn or sugarcane, biodiesel from rapeseed oil) or second generation lignocellulosic-based biofuels (e.g. butanol from wheat straw) [1-3]. However, whilst the production of third generation biofuels has been proven technically feasible, their financial viability and commercial success remains unclear $[4,5]$.

Microalgal biofuels production is currently restricted by the high costs and energy required to first cultivate mass-scale microalgal biomass and subsequently harvest it, leading to non-competitive biofuel prices [6]. A competitive way of maximising the profitability of third generation biofuels is through the implementation of microalgal biorefineries, where the production of biofuels as well as any other value-added chemicals is fully exploited $[3,7,8]$. The biorefinery concept offers plenty of opportunities given that the chemical composition of microalgae is rich in major carbon-based compounds (e.g. carbohydrates, lipids, proteins, vitamins) which act as raw precursors for a large variety of human health-related products (e.g. vitamins and antioxidants), but also for biofuels production $[9,10]$. However, before microalgal biorefineries become commercially successful it is necessary to evaluate and optimally integrate all possible bioprocessing conversion and/or waste revalorisation scenarios [6].

Microalgal lipids can be directed towards biodiesel production via the transesterification reaction, where triacylglycerides (TAGs) are converted into fatty acid methyl esthers (FAMEs, i.e. biodiesel). Meanwhile, microalgal carbohydrates can be directed towards bioethanol or biobutanol production via fermentative processes [8]. The potential for biodiesel and bioethanol production from microalgae has been well documented and investigated in the literature [11-19], but microalgal biobutanol has received less attention [20-22]. Biobutanol is superior to bioethanol since it can be blended with fuels at much higher ratios without requiring modifications to engines [23]. However, biobutanol production is severely restricted by the low product yields of the Acetone-ButanolEthanol (ABE) fermentation, the biochemical route from which this biofuel is produced [24]. Thus, before biobutanol production (whether from microalgae or any other feedstock) becomes an economically viable alternative to the most dominant bioethanol, the low $\mathrm{ABE}$ fermentation yields should be improved. 
$\mathrm{ABE}$ fermentation is carried out by Clostridia species in two-stages: acidogenesis and solventogenesis. During the acidogenesis stage, carbohydrate-rich biomass is first metabolised into organic acids (e.g. acetic acid and butyric acid), which induces the start of the solventogenic phase where accumulated acids are converted into the final ABE products [25,26]. Manipulation of the fermentation media (e.g. type of carbon substrate) including external supplementation of acetic acid and butyric acid (i.e. the major precursors for solventogenesis) have been suggested as strategies for improving butanol yields, provided that an optimal composition is previously identified [27-29].

To evaluate the potential for biobutanol and biodiesel production within a microalgal biorefinery framework, this work aimed to quantify the co-production of microalgal butanol via the $\mathrm{ABE}$ fermentation and the production of microalgal biodiesel via the transesterification reaction. Analysis associated to biobutanol production involved: i) the identification of an optimal fermentation medium composition subject to the initial concentrations of acetic acid, butyric acid, and nitrogen, via glucose-based experimentation; and ii) the subsequent evaluation of microalgal biomass as a fermentation substrate in raw or hydrolysed form. The analysis associated to biodiesel production involved the extraction, quantification, and profiling of lipids from the microalgal biomass, before and after its use as a fermentation substrate.

\section{Materials and Methods.}

\subsection{Preparation of microalgal biomass.}

The microalgal biomass employed in this study originated from Chlamydomonas reinhardtii CCAP 11/32C. The strain was grown mixotrophically in Tris-Acetate-Phosphate (TAP) medium [30] under the environmental conditions described in [31]. Microalgal cultures were harvested at the $7^{\text {th }}$ day by centrifuging cells for $10 \mathrm{~min}$ at 7,500 rpm in an Avanti J-26S XP centrifuge (Beckman Coulter). The pelleted cells were dried for 24 hours at $70{ }^{\circ} \mathrm{C}$ and kept in sealed containers. The process was repeated successively until a stock of $\sim 25 \mathrm{~g}$ of dried biomass was collected. Prior to analyses, dried cells were pulverised manually with mortar and pestle with intermittent supply of liquid nitrogen. Pulverised cells were washed in $70 \%$ ethanol to remove chlorophyll pigments and allowed to dry a second time $\left(24 \mathrm{~h}, 70^{\circ} \mathrm{C}\right)$. The resulting microalgal biomass $(\mathrm{MB})$ was then used as required in $\mathrm{ABE}$ fermentations and transesterification, as per the routes presented in Figure 1.

\subsection{ABE Fermentation.}

\subsubsection{Strain and maintenance.}


ABE fermentation was carried out with Clostridium acetobutylicum DSM 792 (purchased from the Leibniz Institute DSMZ-German Collection of Microorganisms and Cell cultures). The strain was delivered in freeze-dried form and activated as per manufacturer's instructions. The active strain was then incubated anaerobically in $100 \mathrm{~mL}$ of Reinforced Clostridial Medium (RCM, Sigma-Aldrich ${ }^{\circledR}$ ) at $37{ }^{\circ} \mathrm{C}$ for a period of $48 \mathrm{~h}$. The culture was preserved as: i) glycerol stocks kept at $-80{ }^{\circ} \mathrm{C}$, and ii) agar plates (solid RCM) kept at $37{ }^{\circ} \mathrm{C}$ in an anaerobic jar. An active culture of the strain was maintained via weekly inoculation into fresh sterile RCM medium.

\subsubsection{Batch fermentation.}

All fermentations were performed in batch in $125 \mathrm{~mL}$ serum glass bottles $(54 \mathrm{~mm} \times 107 \mathrm{~mm}$, Wheaton) containing $100 \mathrm{~mL}$ of P2 medium $\left(\mathrm{g} \mathrm{L}^{-1}\right)$ : 60 glucose, $0.2 \mathrm{MgSO}_{4} \cdot 7 \mathrm{H}_{2} \mathrm{O}, 0.01$ $\mathrm{MnSO}_{4} \cdot \mathrm{H}_{2} \mathrm{O}, 0.01 \mathrm{FeSO}_{4} \cdot 7 \mathrm{H}_{2} \mathrm{O}, 0.25 \mathrm{~K}_{2} \mathrm{HPO}_{4}, 0.25 \mathrm{KH}_{2} \mathrm{PO}_{4}, 2 \mathrm{NH}_{4} \mathrm{CL}, 1$ yeast extract, and 5 $\mathrm{CaCO}_{3}$ [32]. The medium employed either glucose or microalgal biomass as carbon source. Prior to sterilisation, the medium $\mathrm{pH}$ was adjusted to a starting value of 6.5 using $\mathrm{KOH} 3 \mathrm{M}$ or HCL $3 \mathrm{M}$, as required. The nitrogen sources $\left(\mathrm{NH}_{4} \mathrm{Cl}\right.$ and yeast extract) were prepared and sterilised separately from all other P2 medium components, and then mixed aseptically upon cooling to room temperature. To create anaerobic conditions, sterile P2 medium was flushed with oxygen-free nitrogen gas for 5 min, after which bottles were immediately capped with rubber stoppers and aluminium caps. All capped bottles were connected to a water trap to release pressure build-up from accumulated gases. Fermentation was initiated by inoculating P2 medium with $5 \mathrm{~mL}$ of an active clostridial culture previously grown on $\mathrm{RCM}$ at $37^{\circ} \mathrm{C}$ for $20 \mathrm{~h}$. To measure the cell growth and the production rates of metabolites, $2 \mathrm{~mL}$ samples of the fermentation broth were removed aseptically at regular times and stored at $-20^{\circ} \mathrm{C}$ for analysis. Data were statistically analysed by one-way ANOVA in Origin Pro 2017 (b9.4.1.354).

Glucose-based fermentations were carried out to initially evaluate the effect of supplementing a buffering agent (i.e. $\mathrm{CaCO}_{3}$ ) to fermentation medium, and subsequently the effect of different initial concentrations of butyric acid $\left(B A_{0}=0,2,4\right.$, and $\left.8 \mathrm{~g} \mathrm{~L}^{-1}\right)$, acetic acid $\left(A A_{0}=0,2,4\right.$, and $\left.8 \mathrm{~g} \mathrm{~L}^{-1}\right)$, and nitrogen $\left(N_{0}=2,4\right.$ and $\left.6 \mathrm{~g} \mathrm{NH}_{4} \mathrm{Cl} \mathrm{L}^{-1}\right)$ on $\mathrm{ABE}$ solvents production. In nitrogen-dependent experiments, only the concentration of ammonium chloride $\left(\mathrm{NH}_{4} \mathrm{Cl}\right)$ was varied, whilst keeping yeast extract concentration constant. All other P2 components remained unchanged.

Microalgae-based fermentations were carried out under standardised glucose-based fermentation conditions, but using microalgal biomass $(\mathrm{MB})$, or microalgal biomass hydrolysate as the main carbon substrate. In fermentations with $\mathrm{MB}$, medium was prepared by replacing glucose with 
microalgal biomas at a concentration of $10 \mathrm{~g} \mathrm{~L}^{-1}$, and autoclaved at $120{ }^{\circ} \mathrm{C}$ for $20 \mathrm{~min}$. In fermentations with microalgal hydrolysate, hydrolysis was performed by mixing $10 \mathrm{~g}$ of $\mathrm{MB}$ in 150 $\mathrm{mL}$ of $4 \%(\mathrm{w} / \mathrm{v})$ sulfuric acid $\left(\mathrm{H}_{2} \mathrm{SO}_{4}\right)$, followed by autoclaving at $120^{\circ} \mathrm{C}$ for $20 \mathrm{~min}$. The hydrolysed microalgal biomass $(\mathrm{MB}-\mathrm{H})$ residues were separated by centrifugation (7,500 rpm, $10 \mathrm{~min})$. The hydrolysate was neutralised with $\mathrm{CaCO}_{3}$, and used in fermentations along with all other P2 medium components.

\subsection{Analytical Methods.}

\subsubsection{Cell growth.}

The growth of C. acetobutylicum DSM 792 was quantified by measuring the optical density (OD) at $680 \mathrm{~nm}$. Samples taken from the fermentation broth were diluted in distilled water $(2: 10)$ and measured in a UVmini-1240 spectrophotometer (Shimadzu). The OD was co-related to the cell dry weight by $1 \mathrm{OD}=0.4 \mathrm{~g} \mathrm{CDW}$ [32]. The residual medium $\mathrm{pH}$ was measured off-line in a bench-type HI $2211 \mathrm{pH}$ meter (Hannah Instruments).

\subsubsection{Fermentation substrate and metabolites.}

The residual glucose concentration was measured by High Pressure Liquid Chromatography (HPLC) in a Dionex Ultimate 3000 instrument, using an Aminex HPX-87H (300 x $7.8 \mathrm{~mm})$ column coupled to an RI detector. Sulphuric acid $\left(\mathrm{H}_{2} \mathrm{SO}_{4}\right)$ was employed as mobile phase at a flow rate of $0.6 \mathrm{~mL}$ $\min ^{-1}$ and a temperature of $50{ }^{\circ} \mathrm{C}$. The residual concentrations of acetic acid, butyric acid, acetone, butanol, and ethanol, were measured by Gas Chromatography in an Agilent 7820A system coupled to a Flame Ionisation Detector (GC-FID). Analysis was carried out in a Poraplot Q-HT fused silica column $(10 \mathrm{~m} \times 0.32 \mathrm{~mm})$ using helium as a carrier gas $(160 \mathrm{kPa})$. The temperature of the detector was set to $250{ }^{\circ} \mathrm{C}$. The oven temperature program was set initially at $90{ }^{\circ} \mathrm{C}$ for $2 \mathrm{~min}$, then ramped up to $200{ }^{\circ} \mathrm{C}$ at a rate of $10^{\circ} \mathrm{C} \mathrm{min}^{-1}$, and finally kept at $200{ }^{\circ} \mathrm{C}$ for $4 \mathrm{~min}$. The injection volume and temperature were $2 \mu \mathrm{L}$ (splitless mode) and $225^{\circ} \mathrm{C}$, respectively. The concentration of all metabolites (substrate, organic acids and solvents) was measured through the area of the chromatographic peaks (from either HPLC or GC) using calibration standards of known composition. All samples and calibration standards were diluted in Type-1 grade water and filtered in $0.45 \mathrm{~m}$ nitrocellulose membrane filters.

\subsubsection{Microalgal crude lipid contents.}

The microalgae employed in this work were evaluated for their biodiesel potential by measuring the lipid content and composition of three different biomass conditions: i) microalgal biomass (MB), ii) 
hydrolysed microalgal biomass (MB-H), and iii) microalgal biomass (non-hydrolysed) postfermentation (MB-F). The crude lipid content of all three microalgal biomass conditions (MB, MB$\mathrm{H}$, and MB-F) was quantified by solvent extraction in a ST 243 SOXTEC unit (FOSS), employing a three-stage extraction protocol (extraction, rinsing, and evaporation) as in [33]. Hexane was used as extracting solvent at a temperature of $155^{\circ} \mathrm{C}$. Prior to extraction, dried pulverised samples of the microalgal biomass were placed in $25 \times 60 \mathrm{~mm}$ cellulose extraction thimbles (Whatman ${ }^{\circledR}$ ). The Bligh and Dyer method was used as a reference method for the quantification of Total Lipids [34].

\subsubsection{Microalgal lipid composition.}

To analyise lipid composition, the crude lipids extracted from each microalgal biomass condition were subjected to a base-catalysed room temperature transesterification as suggested by other studies [35,36]. Briefly: i) extracted lipids were diluted in $5 \mathrm{~mL}$ hexane and mixed with $1 \mathrm{~mL}$ of freshly prepared $2 \mathrm{M}$ methanolic $\mathrm{KOH}$ solution, ii) the mixture was shaken for 10 minutes at $50 \mathrm{rpm}$ and phase separation was then achieved by centrifugation at $4000 \mathrm{rpm}$ for 15 minutes, iii) $1 \mathrm{~mL}$ of distilled water was added to the mixture to dissolve any unreacted methanolic $\mathrm{KOH}$ and other impurities, and the mixture was left standing for 2 hours to achieve a biphasic layer, iv) the organic layer was evaporated and reconstituted with $1 \mathrm{~mL}$ of dichloromethane, suitable for gas chromatography analysis. After transesterification, the profiling and quantification of the fatty acid methyl esthers (FAMEs) of all microagal conditions was carried out in a gas chromatography unit (Shimadzu) with mass spectrometry detection (GC-MS). Analysis was performed in a BPX70 column $(60 \mathrm{~m} \times 0.25 \mathrm{~mm} \times 0.25 \mathrm{~mm})$ using helium as a carrier gas $\left(1.5 \mathrm{~mL} \mathrm{~min}^{-1}\right)$. The temperature of the detector was set to $250{ }^{\circ} \mathrm{C}$. The oven temperature program was set initially to $100{ }^{\circ} \mathrm{C}$ for 1 min, then ramped up to $250{ }^{\circ} \mathrm{C}$ at a rate of $5^{\circ} \mathrm{C} \mathrm{min}^{-1}$, and finally kept to $250{ }^{\circ} \mathrm{C}$ for $10 \mathrm{~min}$. The injection volume and temperature were $1 \mu \mathrm{L}$ (split mode $1: 50$ ) and $250^{\circ} \mathrm{C}$, respectively. For FAME quantification, an internal standard of tripentadecanoin (TAG) was added to all microalgal samples prior to crude lipid extractions.

\section{Response surface analysis (RSA) for ABE solvents.}

A response surface analysis (RSA) was carried out to evaluate the production of the three ABE fermentation solvents subject to different initial medium concentrations of acetic acid and butyric acid. Experimental data was generated from glucose-based fermentations (as explained above) following a fractional factorial design considering 2 independent factors (i.e. acetic acid and butyric acid concentrations) at 4 levels each (i.e. $0,2,4$, and $8 \mathrm{~g} / \mathrm{L}$ ), and 8 experimental trials (i.e. half of the experimental trials needed in a full factorial, $4^{2}=16$ ). Response surface curves were generated by 
fitting second-order polynomial equations to the experimental data (first 8 rows in Table 1) via multiple regression analysis. The two-factor quadratic model equations for each of the fermentation products were expressed as in Eq. 1:

$$
\hat{y}=\alpha_{0}+\alpha_{1} \cdot X_{1}+\alpha_{2} \cdot X_{2}+\alpha_{3} \cdot X_{1}{ }^{2}+\alpha_{4} \cdot X_{2}{ }^{2}+\alpha_{5} \cdot X_{1} \cdot X_{2}
$$

Here $\hat{y}$ is the response variable (i.e. acetone, butanol, or ethanol), $X_{1}$ and $X_{2}$ are the independent variables (i.e. acetic acid and butyric acid), $\alpha_{0}$ is the intercept coefficient, $\alpha_{1}$ and $\alpha_{2}$ are the linear regression coefficients, $\alpha_{3}$ and $\alpha_{4}$ are the quadratic regression coefficients, and $\alpha_{5}$ is the interactive regression coefficient.

\subsection{Model fitting.}

The regression coefficients, $\bar{\alpha}=\left[\alpha_{0}, \alpha_{1}, \alpha_{2}, \alpha_{3}, \alpha_{4}, \alpha_{5}\right]$, of the quadratic model (Eq. 1) were estimated by minimising the squared error, $E$, between predicted, $\hat{y}$, and experimental values, $y$, as in Eq. 2:

$$
\min E=\sum_{k=1}^{n}\left(\hat{y}_{k}(\bar{\alpha})-y_{k}\right)^{2}
$$

Here, $n$ represents the number of experimental runs dependent on acetic and/or butyric acid. Data employed for fitting corresponded to the means obtained from three experimental replicates. Eq. 2 was minimised by means of an optimisation algorithm combining both stochastic and deterministic routines [37]. The significance of the estimated regression coefficients in Eq. 1 was evaluated by one-way ANOVA in Origin Pro 2017 (b9.4.1.354).

\section{Results and Discussion.}

The production of microalgal biobutanol and biodiesel via the ABE fermentation and transesterificacion, respectively, was evaluated and quantified using microalgal biomass from the model species $C$. reinhardtii, according to the routes shown in Figure 1.

\subsection{Biobutanol from microalgae.}

\subsubsection{Glucose-based fermentation.}

Glucose-based experiments were carried out to standardise fermentation protocols and obtain butanol production yields comparable to those reported in the literature. In unbuffered fermentations (data included as Supplementaty Information), $\mathrm{pH}$ dropped to values below 4.5 which prevented ABE solvents formation, a phenomenom referred to as "acid crash" whereby only acids are formed at the expense of solvents [38,39]. To avoid acid crash, P2 medium was thus supplemented with $5 \mathrm{~g} \mathrm{~L}^{-1}$ 
$\mathrm{CaCO}_{3}$, as in [32]. Although this buffering agent has not been frequently reported for batch fermentations, $\mathrm{CaCO}_{3}$ allowed $\mathrm{pH}$ to remain above 4.5 which triggered solventogenesis.

Subsequently, the effects of butyric acid $\left(\mathrm{BA}_{0}\right)$, acetic acid $\left(\mathrm{AA}_{0}\right)$, and nitrogen $\left(\mathrm{N}_{0}\right)$, initial concentrations on ABE fermentation dynamics were evaluated. Figure 2 shows datasets obtained from 4 fermentations: i) control fermentation ( $\mathrm{P} 2$ medium: $\mathrm{BAo}=0 \mathrm{~g} \mathrm{~L}^{-1}, \mathrm{AAo}=0 \mathrm{~g} \mathrm{~L}^{-1}$, and $\left.\mathrm{No}=2 \mathrm{~g} \mathrm{NH}_{4} \mathrm{Cl} \mathrm{L}^{-1}\right)$, ii) fermentation with butyric acid at $\mathrm{BAo}=4 \mathrm{~g} \mathrm{~L}^{-1}$, iii) fermentation with acetic acid at $\mathrm{AAo}=4 \mathrm{~g} \mathrm{~L}^{-1}$, and iv) fermentation with nitrogen at $\mathrm{No}=4 \mathrm{~g} \mathrm{NH}_{4} \mathrm{Cl} \mathrm{L}^{-1}$. All other experimental datasets are included as Supplementary Information. Cell growth (Figure 2.a) followed the typical stages of microbial kinetics [40], with a short stationary phase followed by cell death. An initial lag phase of 20-24 h was led by an exponential phase lasting up to the second day (48 h). Most of the glucose was consumed (Figure 2.b), favouring accumulation of organic acids (Figure 2.c, Figure 2.d) and thus a sudden drop in medium $\mathrm{pH}$ (Figure 2.h), all characterisitic of acidogenesis during which fermentation gases (i.e. $\mathrm{H}_{2}$ and $\mathrm{CO}_{2}$ ) are produced [25].

Both the $\mathrm{pH}$ and the organic acids play a key role in triggering solventogenesis $[41,42]$. It has been suggested that for solventogenesis to start, the $\mathrm{pH}$ should fall to within a range of $4.3-5.2$ [43]. The shift between phases is also associated to a specific threshold of organic acids (mostly in undissociated form) which later permeate through the cell membrane to be reassimilated into the ABE solvents [38]. However, medium $\mathrm{pH}$ and organic acid titres must reach optimal levels since high concentration of undissociated acids at low $\mathrm{pH}$ values may induce "acid crash" [44]. ABE solvents formation (responsible for the final increase in $\mathrm{pH}$ ) started at the $48 \mathrm{~h}$ mark and continued up to $100 \mathrm{~h}$. Butanol accumulation is known to disrupt cellular membranes, affecting their permeability and in consequence nutrient uptake processes [26]. Such inhibitory effects can be observed in Figure 2.a, with cell dry weight declining with increasing butanol concentration.

The final fermentation titres and yields of all glucose-based fermentations are summarised in Table 1. The control culture attained final concentrations of $\left(\mathrm{g} \mathrm{L}^{-1}\right): 1.88$ acetone, 12.67 butanol, and 0.92 ethanol. For comparison, butanol concentrations are: i) higher than those reported (in batch) for $C$. acetobutylicum DSM $792\left(\mathrm{~g} \mathrm{~L}^{-1}\right): \sim 1.9$ acetone, $\sim 5.9$ butanol, and $\sim 1$ ethanol [45], and ii) slightly lower than those reported for C. saccharoperbutylacetonicum N1-4 in batch $\left(\mathrm{g} \mathrm{L}^{-1}\right): 3.43$ acetone, 13.64 butanol, and 1.24 ethanol [21].

The culture supplemented with $4 \mathrm{~g} \mathrm{~L}^{-1}$ of butyric acid yielded significantly higher butanol titres $(\mathrm{p}=0.013$. as per one-way ANOVA) and glucose consumption yields $(\mathrm{p}<0.001)$ than the control, and 
overall the highest ABE solvent titres (Table 1). Supplementation of butyric acid (at $\left.4 \mathrm{~g} \mathrm{~L}^{-1}\right)$ has also been shown to increase butanol titres (from $13.5 \mathrm{~g} \mathrm{~L}^{-1}$ to $16.5 \mathrm{~g} \mathrm{~L}^{-1}$ ) and yields (from 0.27 to 0.34 ) in C. acetobutylicum YM1 when grown in batch without $\mathrm{pH}$ control [29]. Similarly, the butanol yield of C. pasteurianum DSM 525 was reported to increase (from 0.31 to $0.38 \mathrm{~g} \mathrm{~g}^{-1}$ ) by butyric acid addition when grown in batch with $\mathrm{pH}$ controlled at 5.3 [46]. Despite this favourable effect, the higher butyric acid concentration of $8 \mathrm{~g} \mathrm{~L}^{-1}$ yielded the lowest substrate consumption yield (64\%), and the lowest acetone $\left(0.79 \mathrm{~g} \mathrm{~L}^{-1}\right)$, butanol $\left(8.72 \mathrm{~g} \mathrm{~L}^{-1}\right)$ and ethanol $\left(0.41 \mathrm{~g} \mathrm{~L}^{-1}\right)$ titres (Table 1). High concentrations of butyric acid (particularly in undissociated form) are considered inhibitory for Clostridial species by unbalancing the $\mathrm{pH}$ gradient across the cell membrane [38]. Results thus suggest that butyric acid medium concentrations should be optimised to avoid potential inhibitory effects.

Acetic acid supplementation did not have a pronounced effect on butanol or ethanol production, but cultures grown in $4 \mathrm{~g} \mathrm{~L}^{-1}$ or $8 \mathrm{~g} \mathrm{~L}^{-1}$ of acetic acid yielded higher acetone titres than the control (Table 1). Increased acetic acid can improve the production of fermentation solvents, but generally favouring acetone production. For example, the supplementation of acetic acid (up to $1 \mathrm{~g} \mathrm{~L}^{-1}$ ) induced acetone formation (with no visibe effects on butanol) in C. acetobutylicum 77 (mutant from ATCC 824) [27]. Meanwhile, in C. saccharoperbutylacetonicum N1-4, the addition of $4 \mathrm{~g} \mathrm{~L}^{-1}$ of acetic acid increased both acetone (from 3.42 to $6.67 \mathrm{~g} \mathrm{~L}^{-1}$ ) and butanol (from 8.90 to $13.2 \mathrm{~g} \mathrm{~L}^{-1}$ ). In addition to acetic acid acting as an additional carbon source, the increase of both acetone and butanol concentration via acetic acid supplementation are attributed to a corresponding increase in the activity of enzymes (i.e. acetoacetoacetase decarboxylase and butanol dehydrogenase) responsible for solvent formation [28].

Interestingly, both nitrogen treatments similarly resulted in higher acetone titres. In fact, the culture grown in $6 \mathrm{~g} \mathrm{~L}^{-1}$ of $\mathrm{NH}_{4} \mathrm{Cl}$ attained the highest acetone titre $\left(2.97 \mathrm{~g} \mathrm{~L}^{-1}\right)$ (Table 1). As observed in Figure 2.c., nitrogen treatment favoured acetic acid formation compared to other treatments, which explains the increased formation of acetone. Nitrogen plays a major role in providing the necessary growth molecules (e.g. nucleic acids and aminoacids) and metabolic energy from the transport of $\mathrm{NH}_{4}^{+}$ions, and can therefore regulate clostridial metabolism and in turn solvent production [47]. However, the specific effects of nitrogen availability on the ABE fermentation have not been yet evaluated in detail in the literature and require further analysis.

\subsubsection{Response surface analysis (RSA).}


To evaluate $\mathrm{ABE}$ solvents formation in response to butyric acid and acetic acid supplementation, surface response curves were generated by fitting a polynomial equation model (Eq. 1) to the experimental data in Table 1. The estimated regression coefficients of the corresponding polynomial equations are presented in Table 2. The polynomial models for acetone, butanol, and ethanol formation displayed co-relation coefficients $\left(R^{2}\right)$ of $0.87,0.91$, and 0.82 , respectively, indicating a fair level of fit to explain the formation of $\mathrm{ABE}$ solvents (i.e. dependent variables) in terms of the initial acetic acid and butyric acid concentrations (i.e. independent variables). The 3D surface responses obtained by each of the resulting model equations are presented in Figure 3.

As per the RSA, butyric acid exhibits a stronger effect than acetic acid on the formation of all the fermentation solvents. In particular, the surface curves show the inhibitory effects of increased butyric acid concentration, which agrees with experimental observations. The pronounced effects of butyric acid over acetic acid are also evidenced by the statistical significance of the regression coefficients directly associated to butyric acid (Table 2). As per the analysis, regression coefficients with a p-value lower than 0.05 indicate a high significance for its corresponding factor and thus a high effect on the response variable. As observed in Table 2, the regression coefficients with pvalues higher than 0.05 (not significant) are mostly associated to acetic acid, specifically its quadratic effects (i.e. $\alpha_{3} \cdot X_{1}^{2}$ ) on all three response variables (acetone, butanol, and ethanol), and its linear effect (i.e. $\alpha_{1} \cdot X$ ) on ethanol. Butyric acids effects can be considered insignificant only by their interaction with acetic acid (i.e. $\alpha_{5} \cdot X_{1} \cdot X_{2}$ ) on butanol and ethanol.

3D surface responses are a graphical tool to evaluate the effects of multiple factors on a response variable, and have been used to optimise biological processes $[48,49]$. Here, the response surface curve for butanol (Figure 3.b) indicated that a maximum butanol concentration of $14.77 \mathrm{~g} \mathrm{~L}^{-1}$ could be attained by supplementing fermentation medium with $0.1 \mathrm{~g} \mathrm{~L}^{-1}$ of acetic acid and $3 \mathrm{~g} \mathrm{~L}^{-1}$ of butyric acid. However, the following points should be made clear: i) variables used in surface response analyses should be noise-free, but those measured here (i.e. acetone, butanol, and ethanol) were subject to various fermentation-related factors difficult to control, and whilst standard deviations were computed the RSA employed only the means of three experimental replicates; ii) the analysis presented here was done a posteriori, and despite the fair level of fit of the polynomial models, surface response analyses require the evaluation of more factor levels (i.e. concentrations) and the interactions between them.

\subsubsection{Microalgae-based fermentation.}


The sugars synthesized by microalgae biomass are accumulated as polymeric carbohydrates, such as starch, glycogen, or celluloses [50]. C. reinhardtii, for example, is a model microalgae known to accumulate carbohydrate in the form of starch granules within the chloroplasts [51], and routine inhouse quantification analyses of the this strain have revealed starch contents in the range of $7-12$ $\%$. Before being used as fermentation subtrate, starch or any other stored carbohydrate needs to be degraded to fermentable sugars (e.g. monomeric molecules such as glucose). However, the ABE fermentation offers a potential advantage over traditional ethanol fermentations given that Clostridial species have long been known to have the ability of degrading starchy biomass (Jones and Woods, 1986). We therefore carried out a fermentation with microalgal biomass (MB), and with microalgal hydrolysate (derived from MB-H). In both cases, fermentation media was supplemented with $\sim 3 \mathrm{~g}$ $\mathrm{L}^{-1}$ of butyric acid since this concentration was identified as the optimal for glucose-based fermentations in the RSA. The results of these fermentations are presented in Figure 4.

As observed in Figure 4.a, cell growth took place in both fermentations, but the the highest cell dry weight was attained by the microalgal hydrolysate. No lag-phase was observed in neither of these fermentations, and unlike in glucose-based fermentations, cells remained in a stationary phase which can be explained due to the lack of butanol inhibition. The HPLC analysis of the microalgal hydrolysate (from MB-H) yielded a glucose concentration of $10.94 \mathrm{~g} \mathrm{~L}^{-1}$ of glucose, which was then slightly diluted to an initial substrate concentration of $8.86 \mathrm{~g} \mathrm{~L}^{-1}$ upon mixing with the remaining P2 medium components. For comparison purposes, the fermentation with microalgal biomass (MB) was carried out at a concentration of $10 \mathrm{~g} \mathrm{~L}^{-1}$ of biomass (dry weight). As observed in Figure 4.b, most of the glucose in the hydrolysate was completely consumed within $24 \mathrm{~h}$. Glucose was not detected in the fermentation with (non-hydrolysed) microalgal biomass (MB), except during the last days in low concentrations which could have resulted from a gradual solubilisation effect of the starch degrading enzymes (e.g.amylases and glucoamylases) synthesized by clostridial species [52]. Both fermentations produced organic acids, but the initial rate of acid production was higher in the fermentation with microalgal hydrolysate, possibly due to the substrate (glucose) being already available in soluble form.

Microalgae-based fermentations produced up to $1.031 \mathrm{~g} \mathrm{~L}^{-1}$ (with $\mathrm{MB}$ ) and $0.89 \mathrm{~g} \mathrm{~L}^{-1}$ (with hydrolysate derived from MB-H) of butanol (Figure 4.f). It was also observed that butanol formation started sooner in the fermentation with hydrolysate as a result of organic acids being accumulated at a faster rate. Acetone and ethanol solvents were produced in very low quantities (or not detected during analysis). The final substrate to butanol yield of the fermentation with microalgal biomass 
was $10.31 \%$ (i.e. $100 \times 1.03 / 10 \mathrm{~g} \mathrm{~g}^{-1}$ of MBCDW), slightly higher than that attained by the microalgal hydrolysate, estimated as $10.07 \%$ (i.e. $100 \times 0.89 / 8.86 \mathrm{~g} \mathrm{~g}^{-1}$ of glucose).

As shown in Figure 1, MB and MB-H were initially subjected to manual pulverisation and freeze drying (with liquid nitrogen). Both samples subsequently underwent an identical high-temperature treatment performed either for sterilisation in $\mathrm{MB}$, or for acid hydrolysis in $\mathrm{MB}-\mathrm{H}$ to convert polysaccharides to monomeric sugars (e.g. glucose). As per the computed butanol yields, the fermentation in $\mathrm{MB}$ (where pulverisation, freeze drying, and sterilisation favoured cell lysis and polysaccharide extraction) performed slightly better than the fermentation in microalgal hydrolysate, suggesting that the additional acid hydrolysis pre-treatment step could be avoided in favour of reducing substrate processing costs. Nevertheless, the following remarks should be addressed: i) the slightly lower titres attained by the hydrolysate may be the result of inhibitory compounds (e.g. furfural or phenolic compounds) typically released during acid treatments [53], and ii) the working temperature of the acid treatment, a critical parameter that increases or decreases extraction efficiencies (Harun and Danquah 2011), may not allow an efficient release of monomeric sugars.

Although the butanol production yields of microalgae-based fermentations $(10.07 \%, 10.31 \%)$ were much lower than those of glucose-based fermentations (up to $30 \%$, Table 1), yields obtained in this work are not far from those reported by other microalgae-driven fermentations (Table 4). [53]. It should be mentioned, however, that $\mathrm{ABE}$ fermentations typically employ $60 \mathrm{~g} \mathrm{~L}^{-1}$ of substrate (e.g. glucose) to obtain appropriate solvent titres [54], but the limited microalgal biomass stock collected in this study restricted this concentration to be used. The low biomass (and sugar) productivity attained by microalgae is actually regarded as critical bottleneck of biofuel-oriented algal cultivation $[55,56]$. In this regard, species selection is a major bioprocess consideration given that algae-driven fermentations, for example, could greatly benefit from the use of species much better suited for carbohydrate accumulation such as Spirogyra sp. or Scenedesmus sp. where carbohydrate contents over $50 \%$ of the cell dry weight are reported [57].

\subsection{Biodiesel from microalgae.}

Crude lipids from microalgae biomass consist of neutral, polar, and non-fatty acid lipids and other contaminants such as ketones, chlorophyll, and proteins. However, only neutral or non-polar lipids (e.g. FAMEs such as TAG) are saponifiable, meaning they can be converted by transesterification to biodiesel. Therefore, due to a non-polar nature with high selectivity towards TAGs, hexane has been the preferred solvent to favour extraction of saponifiable lipids [35]. 
The hexane-extracted crude lipid content from the raw microalgal biomass (MB) was $4.25 \%$, slightly lower than the lipids extracted from the hydrolysed microalgal biomass (MB-H) residues, quantified as $6.8 \%$, and the fermented microalgal biomass (MB-F), quantified as $6.5 \%$. Cell disruption can improve the efficiency of solvent-based extractions due to a higher interfacial area between solvent and cells [35]. Therefore, although all three biomass samples were subjected to manual pulverisation and freeze-drying, the difference in extracted lipids obtained here can be explained by the higher degree of cell disruption achieved by either the additional high-temperature treatment (sterilisation) carried out in MB-F, or the high-temperature acid hydrolysis carried out in MB-H (Figure 1). Such pre-treatments were additionally observed to be favourable for extracting saponifiable lipids (i.e. FAMEs), determined as per Eq. 3:

$$
\text { Saponifiable lipids }(\%)=\frac{\text { FAME content }(\mathrm{mg} / \mathrm{g} \text { CDW })}{\text { Extracted crude lipids }(\mathrm{mg} / \mathrm{g} \mathrm{CDW})} \cdot 100 \quad \text { Eq. (3) }
$$

In Eq. (3), the FAME contents were obtained via chromatographic analysis (Figure 5.a). The raw microalgal biomass yielded the lowest saponifiable lipids (MB at $21.62 \%$ ) against the hydrolysed microalgal biomass (MB-H at $56.1 \%$ ) or the fermented microalgal biomass (MB-F at $49.9 \%$ ). The additional disruptive treatments employed here proved beneficial for biodiesel production as they facilitated extraction of the valuable saponifiable lipids. Whilst the disruption processes carried out in this work included high-temperature and acid hydrolysis, other pre-treatment methods shown to facilitate exposure of lipids include ultrasound, microwave, pressing, osmotic shock, enzyme or chemical breakdown, among others. The selection of the most efficient disruption process is an important consideration for algae-derived biodiesel production that should take into account, on one hand the diverse cell morphology and lipid composition of algal species, and on the other the energy consumption and treatment costs [58].

\subsubsection{Fatty acid methyl ester (FAME) profile and biodiesel yield.}

As observed in Figure 5.b, the FAME composition (e.g. saturated, unsaturated, and polyunsaturated fatty acids) was esentially the same across all three biomass conditions. This was expected since all samples, regardless of pretreatment, originated from a stock of biomass collected from a pure algal culture (i.e. C. reinhardtii CCAP11/32C). Although studies may employ FAMEs as internal standards during chromatographic analysis [59,60], here a TAG (tripentadecanoin) was used to account for the potential loss of analyte during both extraction and transesterification processes given that similar losses would be experienced by the standard and the microalgal lipids. In addition, 
tripentadecanoin consists of $3 \mathrm{C} 15: 0$ and does not interfere with microalgal lipids containing TAGs with even numbers [36].

The complete FAME profile is shown in Table 3. In all cases, the most dominant FAMEs were palmitic acid (C16:0), oleic acid (C18:1), linoleic acid (C18:2), and linolenic acid (C18:3). Other FAMEs also present were palmitoleic acid (C16:1), hexadecadienoic acid (C16:2), and stearic acid (C18:0). These FAMEs correspond to the most relevant fatty acids for biofuel production [36,61], and linolenic acid (C18:3) is an essential fatty acid for human health that has also been identified in Picochlorum sp. [62]. Overall, most of the important fatty acids were dominantly present in the three FAME profiles shown in Table 3, which are in agreement with other microalgae. C16:0 and C18:13, for instance, have been reported as the FAMEs with greater percent composition in C. reinhardtii CC123 [63], Chlorella vulgaris, Nannochloropsis sp. [36], and also in mixed algal cultures rich in Oscillatoria sp., Cyclotella sp., and Scenedesmus sp. [15]. Although FAME composition might be similar among microalgae species, it is worth mentioning that FAME contents and productivities can be subject to cultivation conditions (e.g. growth via: $\mathrm{CO}_{2}$, carbonate, air, nitrogen depleteion; or harvesting time, etc) [63,64], which offers the potential to identify optimal biodiesel-oriented strategies.

The yield of biodiesel (FAMEs) produced from all three biomass conditions was calculated using Eq. 4 [36]:

$$
\text { Biodiesel (FAME) yield } \%=\frac{\text { FAME content }(\mathrm{mg} / \mathrm{g} \mathrm{CDW})}{\text { Total lipid content }(\mathrm{mg} / \mathrm{g} \mathrm{CDW})} \cdot 100 \quad \text { Eq. (4) }
$$

The Total lipid content (as per the Bligh and Dyer method) was $158 \mathrm{mg} \mathrm{g}^{-1}$ of cell dry weight (CDW) of microalgal biomass (or $15.58 \%$ ). As shown in Table 3, the highest FAME content was derived from the MB-H condition at $38.2 \mathrm{mg} \mathrm{g}^{-1} \mathrm{CDW}$ (i.e. $3.82 \%$ per $\mathrm{CDW}$ ), followed by MB-F condition at $32.9 \mathrm{mg} \mathrm{g}^{-1} \mathrm{CDW}$ (i.e. $3.29 \%$ per CDW). The lowest FAME content was provided by the initial $\mathrm{MB}$, with only $9.2 \mathrm{mg} \mathrm{g}^{-1} \mathrm{CDW}$ (i.e. $0.92 \%$ per CDW). This indicated that MB-H and MB-F provided the highest biodiesel (FAME) yields (Eq. 4), at 24.16\% and 20.80\%, respectively. Meanwhile, MB provided a biodiesel yield of 5.82\%. Again, the higher biodiesel yields of MB-H and MB-F can be attributed to their higher level of cell disruption. A comparison between the microalgal pre-treatment steps and corresponding biodiesel (FAME) content obtained in this study and others reported in the literature is presented in Table 4.

\subsection{Microalgal biorefineries - the outlook.}


The exploitation of microalgal biomass can yield energy-rich products such as syngas, charcoal, biooil, electricity, methane, or liquid biofuels via various thermochemical (e.g. pyrolysis, gasification, thermal liquefaction) or biochemical (e.g. anaerobic digestion, fermentation, transesterification) conversion processes. Additionally, other bioactive compounds (e.g. fatty acids, carotenoids, pigments) important for human nutrition and health can be derived from microalgae [3]. Therefore, the biorefinery concept allows for all potential biomass side-products and/or waste to be re-valorised, increasing energy efficiency and process profitability by capitalising from both the typical "high volume low price" and the "low volume high price" bioprocessing strategies.

The successful establishement of microalgae-based biorefineries, however, requires the evaluation and analysis of all possible co-production scenarios rather than a single-product approach. In this work, we explored two biochemical conversion routes corresponding to the production of biobutanol and biodiesel. The conversion routes (i.e. ABE fermentation and transesterification) were evaluated under a two-step sequential approach whereby biomass was first fermented - either in raw or hydrolysed form - to produce biobutanol, and then transesterified to produce biodiesel (green and blue routes, Figure 1). Although butanol production was not observed to be influenced by whether fermentation was carried out with microalgal biomass or microalgal hydrolysate, biodiesel production was indeed observed to be affected by the type of cell disruption treatment the biomass was subjected to. Results thus highlight the need to optimally select energy-efficient but low-cost pre-treatment steps that maximise cell disruption and thus product recovery, which is one of the main considerations for optimal biorefinery design [65].

Whilst the biofuel yields quantified here are comparable to those obtained in other studies (Table 4) and reaffirm the potential of microalgae as a platform for value-added chemicals, these yields do not guarantee a positive energy balance that can compete with fossil fuels production [66], or even with other biofuel processes (e.g. bioethanol yield from algae-based fermentation has been estimated as high as $38 \%$ ) [17]. Given that algal fuel processes still lack technological developments to satisfy global biofuel demands [67], further research is required to address challenges associated to microalgae-based biofuels production at all steps of the production chain, including cultivation and harvesting. In this regard, the chemical composition of microalgae plays a critical role within a biorefinery framework as it elucidates the bioprocessing conversion strategies with viable commercial applications. Therefore, the renowned ability of microalgae to alter their composition in response to cultivation conditions (e.g. nutrient availability, light intensity, temperature, etc.) offers plenty of opportunities through the identification of tailor-made cultivation strategies maximising 
carbohydrate and/or lipid formation, suitable for the successful establishment of biofuel-oriented microalgal biorefineries as we have highlighted in recent works $[31,68]$.

\section{Conclusions.}

This work quantified the production of of biobutanol (via the ABE fermentation) and biodiesel (via transesterification) using microalgal biomass from the model species $C$. reinhardtii. The microagal biomass was subjected to different pretreatment methods including pulverisation, sterilisation, and acid hydrolysis at high temperature. Biobutanol yields of $10.31 \%$ and $10.07 \%$ were obtained when using microalgal biomass or microalgal hydrolysate, respectively. The biodiesel (FAME) content of the fermented microalgal biomass and the hydrolysed biomass residues were $3.29 \%$ and $3.82 \%$, respectively, much higher than that of the raw microalgal biomass $(0.92 \%)$, which highlighted the benefits of cell disruption via different pre-treatment methods. Whilst further research is required to improve microalgal biofuel production yields, results are a step forward towards developing optimal microalgal biorefineries.

\section{Acknowledgements}

Gonzalo M. Figueroa-Torres kindly acknowledges the Mexican National Council of Science and Technology (CONACyT) for its financial support. Wan M. Asyraf would like to acknowledge the Ministry of Education (MoE) Malaysia for financially supporting this project and granting a predoctoral scholarship.

\section{References}

[1] M.J. Groom, E.M. Gray, P.A. Townsend, Biofuels and Biodiversity: Principles for Creating Better Policies for Biofuel Production, Conserv. Biol. 22 (2008) 602-609. doi:10.1111/j.1523-1739.2007.00879.x.

[2] N. Qureshi, B.C. Saha, M. a Cotta, Butanol production from wheat straw hydrolysate using Clostridium beijerinckii., Bioprocess Biosyst. Eng. 30 (2007) 419-27. doi:10.1007/s00449007-0137-9.

[3] T. Suganya, M. Varman, H.H. Masjuki, S. Renganathan, Macroalgae and microalgae as a potential source for commercial applications along with biofuels production: A biorefinery approach, Renew. Sustain. Energy Rev. 55 (2016) 909-941. doi:10.1016/j.rser.2015.11.026.

[4] L. Zhu, Biorefinery as a promising approach to promote microalgae industry: An innovative framework, Renew. Sustain. Energy Rev. 41 (2015) 1376-1384.

doi:10.1016/j.rser.2014.09.040.

[5] J.W. Richardson, M.D. Johnson, J.L. Outlaw, Economic comparison of open pond raceways to photo bio-reactors for profitable production of algae for transportation fuels in the Southwest, Algal Res. 1 (2012) 93-100. doi:10.1016/J.ALGAL.2012.04.001. 
[6] I. Hariskos, C. Posten, Biorefinery of microalgae - opportunities and constraints for different production scenarios., Biotechnol. J. 9 (2014) 739-52. doi:10.1002/biot.201300142.

[7] L. Barsanti, P. Gualtieri, Is exploitation of microalgae economically and energetically sustainable?, Algal Res. 31 (2018) 107-115. doi:10.1016/J.ALGAL.2018.02.001.

[8] J. Trivedi, M. Aila, D.P. Bangwal, S. Kaul, M.O. Garg, Algae based biorefinery-How to make sense?, Renew. Sustain. Energy Rev. 47 (2015) 295-307.

doi:10.1016/J.RSER.2015.03.052.

[9] M.K. Enamala, S. Enamala, M. Chavali, J. Donepudi, R. Yadavalli, B. Kolapalli, T.V. Aradhyula, J. Velpuri, C. Kuppam, Production of biofuels from microalgae - A review on cultivation, harvesting, lipid extraction, and numerous applications of microalgae, Renew. Sustain. Energy Rev. 94 (2018) 49-68. doi:10.1016/J.RSER.2018.05.012.

[10] C.-Y. Chen, X.-Q. Zhao, H.-W. Yen, S.-H. Ho, C.-L. Cheng, D.-J. Lee, F.-W. Bai, J.-S. Chang, Microalgae-based carbohydrates for biofuel production, Biochem. Eng. J. 78 (2013) 1-10. doi:10.1016/j.bej.2013.03.006.

[11] Y. Chisti, Biodiesel from microalgae, Biotechnol. Adv. 25 (2007) 294-306. doi:10.1016/J.BIOTECHADV.2007.02.001.

[12] J. Liu, J. Huang, Z. Sun, Y. Zhong, Y. Jiang, F. Chen, Differential lipid and fatty acid profiles of photoautotrophic and heterotrophic Chlorella zofingiensis: Assessment of algal oils for biodiesel production, Bioresour. Technol. 102 (2011) 106-110. doi:10.1016/J.BIORTECH.2010.06.017.

[13] H. Xu, X. Miao, Q. Wu, High quality biodiesel production from a microalga Chlorella protothecoides by heterotrophic growth in fermenters, J. Biotechnol. 126 (2006) 499-507. doi:10.1016/J.JBIOTEC.2006.05.002.

[14] S. Lage, F.G. Gentili, Quantification and characterisation of fatty acid methyl esters in microalgae: Comparison of pretreatment and purification methods, Bioresour. Technol. 257 (2018) 121-128. doi:10.1016/J.BIORTECH.2018.01.153.

[15] S.B. Velasquez-Orta, R. Garcia-Estrada, I. Monje-Ramirez, A. Harvey, M.T. Orta Ledesma, Microalgae harvesting using ozoflotation: Effect on lipid and FAME recoveries, Biomass and Bioenergy. 70 (2014) 356-363. doi:10.1016/J.BIOMBIOE.2014.08.022.

[16] R. Harun, J.W.S. Yip, S. Thiruvenkadam, W.A.W.A.K. Ghani, T. Cherrington, M.K. Danquah, Algal biomass conversion to bioethanol - a step-by-step assessment, Biotechnol. J. 9 (2014) 73-86. doi:10.1002/biot.201200353.

[17] R. Harun, M.K. Danquah, G.M. Forde, Microalgal biomass as a fermentation feedstock for bioethanol production, J. Chem. Technol. Biotechnol. 85 (2010) 199-203. doi:10.1002/jctb.2287.

[18] K.H. Kim, I.S. Choi, H.M. Kim, S.G. Wi, H.-J. Bae, Bioethanol production from the nutrient stress-induced microalga Chlorella vulgaris by enzymatic hydrolysis and immobilized yeast fermentation, Bioresour. Technol. 153 (2014) 47-54. doi:https://doi.org/10.1016/j.biortech.2013.11.059.

[19] J. Rojan P, G.S. Anisha, K.M. Nampoothiri, A. Pandey, Micro and macroalgal biomass: a renewable source for bioethanol., Bioresour. Technol. 102 (2011) 186-93. 
doi:10.1016/j.biortech.2010.06.139.

[20] Y. Wang, W. Guo, C.-L. Cheng, S.-H. Ho, J.-S. Chang, N. Ren, Enhancing bio-butanol production from biomass of Chlorella vulgaris JSC-6 with sequential alkali pretreatment and acid hydrolysis, Bioresour. Technol. 200 (2016) 557-564.

doi:10.1016/j.biortech.2015.10.056.

[21] J.T. Ellis, N.N. Hengge, R.C. Sims, C.D. Miller, Acetone, butanol, and ethanol production from wastewater algae., Bioresour. Technol. 111 (2012) 491-5. doi:10.1016/j.biortech.2012.02.002.

[22] E.N. Efremenko, a B. Nikolskaya, I. V Lyagin, O. V Senko, T. a Makhlis, N. a Stepanov, O. V Maslova, F. Mamedova, S.D. Varfolomeev, Production of biofuels from pretreated microalgae biomass by anaerobic fermentation with immobilized Clostridium acetobutylicum cells., Bioresour. Technol. 114 (2012) 342-8. doi:10.1016/j.biortech.2012.03.049.

[23] S.B. Bankar, S. a. Survase, H. Ojamo, T. Granström, Biobutanol: the outlook of an academic and industrialist, RSC Adv. 3 (2013) 24734. doi:10.1039/c3ra43011a.

[24] V. García, J. Päkkilä, H. Ojamo, E. Muurinen, R.L. Keiski, Challenges in biobutanol production: How to improve the efficiency?, Renew. Sustain. Energy Rev. 15 (2011) 964980. doi:10.1016/j.rser.2010.11.008.

[25] M. Köpke, P. Dürre, Handbook of biofuels production, Elsevier, 2011. doi:10.1533/9780857090492.2.221.

[26] M. Kumar, K. Gayen, Developments in biobutanol production: New insights, Appl. Energy. 88 (2011) 1999-2012. doi:10.1016/j.apenergy.2010.12.055.

[27] G. Matta-El-Ammouri, R. Janati-Idrissi, A.-M. Junelles, H. Petitdemange, R. Gay, Effects of butyric and acetic acids on acetone-butanol formation by Clostridium acetobutylicum, Biochimie. 69 (1987) 109-115. doi:10.1016/0300-9084(87)90242-2.

[28] Q. Zhou, Y. Liu, W. Yuan, Kinetic modeling of lactic acid and acetic acid effects on butanol fermentation by Clostridium saccharoperbutylacetonicum, Fuel. 226 (2018) 181-189. doi:10.1016/J.FUEL.2018.04.019.

[29] N.K.N. Al-Shorgani, M.S. Kalil, W.M.W. Yusoff, A.A. Hamid, Impact of pH and butyric acid on butanol production during batch fermentation using a new local isolate of Clostridium acetobutylicum YM1, Saudi J. Biol. Sci. 25 (2018) 339-348. doi:10.1016/J.SJBS.2017.03.020.

[30] E.H. Harris, The Chlamydomonas sourcebook : a comprehensive guide to biology and laboratory use, Academic Press, 1989.

[31] G.M. Figueroa-Torres, J.K. Pittman, C. Theodoropoulos, Kinetic modelling of starch and lipid formation during mixotrophic, nutrient-limited microalgal growth, Bioresour. Technol. 241 (2017) 868-878. doi:10.1016/j.biortech.2017.05.177.

[32] F. Raganati, A. Procentese, G. Olivieri, P. Götz, P. Salatino, A. Marzocchella, Kinetic study of butanol production from various sugars by Clostridium acetobutylicum using a dynamic model, Biochem. Eng. J. 99 (2015) 156-166. doi:10.1016/j.bej.2015.03.001. 
[33] M. Bekirogullari, I.S. Fragkopoulos, J.K. Pittman, C. Theodoropoulos, Production of lipidbased fuels and chemicals from microalgae: An integrated experimental and model-based optimization study, Algal Res. 23 (2017) 78-87. doi:10.1016/j.algal.2016.12.015.

[34] E.G. Bligh, W.J. Dyer, A rapid method of total lipid extraction and purification, Can. J. Biochem. Physiol. 37 (1959) 911-917. doi:10.1139/o59-099.

[35] V.C.A. Orr, N. V Plechkova, K.R. Seddon, L. Rehmann, Disruption and Wet Extraction of the Microalgae Chlorella vulgaris Using Room-Temperature Ionic Liquids, ACS Sustain. Chem. Eng. 4 (2016) 591-600. doi:10.1021/acssuschemeng.5b00967.

[36] W.M.A. Wan Mahmood, C. Theodoropoulos, M. Gonzalez-Miquel, Enhanced microalgal lipid extraction using bio-based solvents for sustainable biofuel production, Green Chem. 19 (2017) 5723-5733. doi:10.1039/C7GC02735D.

[37] A. Vlysidis, M. Binns, C. Webb, C. Theodoropoulos, Glycerol utilisation for the production of chemicals: Conversion to succinic acid, a combined experimental and computational study, Biochem. Eng. J. 58-59 (2011) 1-11. doi:10.1016/j.bej.2011.07.004.

[38] D.L. Bryant, H.P. Blaschek, Buffering as a means for increasing growth and butanol production byClostridium acetobutylicum, J. Ind. Microbiol. 3 (1988) 49-55. doi:10.1007/BF01569442.

[39] S.H. Wang, Y.P. Zhang, H.J. Dong, S.M. Mao, Y. Zhu, R.J. Wang, G.D. Luan, Y. Li, Formic acid triggers the "acid crash" of acetone-butanol-ethanol fermentation by clostridium acetobutylicum, Appl Env. Microb. 77 (2011). doi:10.1128/AEM.01835-10.

[40] M.L. Shuler, F. Kargi, Bioprocess Engineering: Basic Concepts, Prentice Hall, 1992.

[41] X. Yang, M. Tu, R. Xie, S. Adhikari, Z. Tong, A comparison of three $\mathrm{pH}$ control methods for revealing effects of undissociated butyric acid on specific butanol production rate in batch fermentation of Clostridium acetobutylicum, AMB Express. 3 (2013) 3. doi:10.1186/2191-0855-3-3.

[42] S. Wang, Y. Zhang, H. Dong, S. Mao, Y. Zhu, R. Wang, G. Luan, Y. Li, Formic Acid Triggers the "Acid Crash" of Acetone-Butanol-Ethanol Fermentation by Clostridium acetobutylicum, Appl. Environ. Microbiol. 77 (2011) 1674-1680. doi:10.1128/AEM.0183510.

[43] L. Yerushalmi, B. Volesky, J. Votruba, Modelling of culture kinetics and physiology for c. acetobutylicum, Can. J. Chem. Eng. 64 (1986) 607-616. doi:10.1002/cjce.5450640411.

[44] X. Yang, M. Tu, R. Xie, S. Adhikari, Z. Tong, A comparison of three $\mathrm{pH}$ control methods for revealing effects of undissociated butyric acid on specific butanol production rate in batch fermentation of Clostridium acetobutylicum, AMB Express. 3 (2013) 3. doi:10.1186/2191-0855-3-3.

[45] S.A. Survase, A. van Heiningen, T. Granström, Continuous bio-catalytic conversion of sugar mixture to acetone--butanol--ethanol by immobilized Clostridium acetobutylicum DSM 792, Appl. Microbiol. Biotechnol. 93 (2012) 2309-2316. doi:10.1007/s00253-011-3761-x.

[46] L. Regestein, E.W. Doerr, A. Staaden, L. Rehmann, Impact of butyric acid on butanol formation by Clostridium pasteurianum, Bioresour. Technol. 196 (2015) 153-159. doi:10.1016/J.BIORTECH.2015.07.085. 
[47] J.W. Roos, J.K. McLaughlin, E.T. Papoutsakis, The effect of pH on nitrogen supply, cell lysis, and solvent production in fermentations ofClostridium acetobutylicum, Biotechnol. Bioeng. 27 (1985) 681-694. doi:10.1002/bit.260270518.

[48] G. Dragone, B.D. Fernandes, A.P. Abreu, A. a. Vicente, J. a. Teixeira, Nutrient limitation as a strategy for increasing starch accumulation in microalgae, Appl. Energy. 88 (2011) 33313335. doi:10.1016/j.apenergy.2011.03.012.

[49] C. Khunchantuek, K. Fiala, Optimization of Key Factors Affecting Butanol Production from Sugarcane Juice by Clostridium beijerinckii TISTR 1461, Energy Procedia. 138 (2017) 157162. doi:10.1016/J.EGYPRO.2017.10.143.

[50] M.I. Khan, J.H. Shin, J.D. Kim, The promising future of microalgae: current status, challenges, and optimization of a sustainable and renewable industry for biofuels, feed, and other products, Microb. Cell Fact. 17 (2018) 36. doi:10.1186/s12934-018-0879-X.

[51] S.G. Ball, P. Deschamps, The Chlamydomonas Sourcebook: Starch Metabolism, Elsevier, 2009. doi:10.1016/B978-0-12-370873-1.00009-5.

[52] D.T. Jones, D.R. Woods, Acetone-butanol fermentation revisited., Microbiol. Rev. 50 (1986) 484-524. http://www.ncbi.nlm.nih.gov/pmc/articles/PMC373084/.

[53] M. Yang, S. Kuittinen, J. Zhang, J. Vepsäläinen, M. Keinänen, A. Pappinen, Cofermentation of hemicellulose and starch from barley straw and grain for efficient pentoses utilization in acetone-butanol-ethanol production, Bioresour. Technol. 179 (2015) 128-135. doi:10.1016/j.biortech.2014.12.005.

[54] N. Qureshi, X.-L. Li, S. Hughes, B.C. Saha, M. a Cotta, Butanol production from corn fiber xylan using Clostridium acetobutylicum., Biotechnol. Prog. 22 (2006) 673-80. doi:10.1021/bp050360w.

[55] Y.-C. Lee, K. Lee, Y.-K. Oh, Recent nanoparticle engineering advances in microalgal cultivation and harvesting processes of biodiesel production: A review, Bioresour. Technol. 184 (2015) 63-72. doi:10.1016/J.BIORTECH.2014.10.145.

[56] J. Kim, G. Yoo, H. Lee, J. Lim, K. Kim, C.W. Kim, M.S. Park, J.-W. Yang, Methods of downstream processing for the production of biodiesel from microalgae, Biotechnol. Adv. 31 (2013) 862-876. doi:10.1016/J.BIOTECHADV.2013.04.006.

[57] L.D. Zhu, E. Hiltunen, E. Antila, J.J. Zhong, Z.H. Yuan, Z.M. Wang, Microalgal biofuels: Flexible bioenergies for sustainable development, Renew. Sustain. Energy Rev. 30 (2014) 1035-1046. doi:10.1016/j.rser.2013.11.003.

[58] M.L. Menegazzo, G.G. Fonseca, Biomass recovery and lipid extraction processes for microalgae biofuels production: A review, Renew. Sustain. Energy Rev. 107 (2019) 87-107. doi:10.1016/J.RSER.2019.01.064.

[59] R. Halim, M.K. Danquah, P.A. Webley, Extraction of oil from microalgae for biodiesel production: A review, Biotechnol. Adv. 30 (2012) 709-732. doi:10.1016/J.BIOTECHADV.2012.01.001.

[60] J. Pan, T. Muppaneni, Y. Sun, H.K. Reddy, J. Fu, X. Lu, S. Deng, Microwave-assisted extraction of lipids from microalgae using an ionic liquid solvent [BMIM][HSO4], Fuel. 178 (2016) 49-55. doi:10.1016/J.FUEL.2016.03.037. 
[61] R. Halim, B. Gladman, M.K. Danquah, P.A. Webley, Oil extraction from microalgae for biodiesel production, Bioresour. Technol. 102 (2011) 178-185.

doi:10.1016/J.BIORTECH.2010.06.136.

[62] F. Yang, W. Xiang, X. Sun, H. Wu, T. Li, L. Long, A Novel Lipid Extraction Method from Wet Microalga Picochlorum sp. at Room Temperature, Mar. Drugs. 12 (2014). doi:10.3390/md12031258.

[63] E.J. Lohman, R.D. Gardner, L.D. Halverson, B.M. Peyton, R. Gerlach, Carbon partitioning in lipids synthesized by Chlamydomonas reinhardtii when cultured under three unique inorganic carbon regimes, Algal Res. 5 (2014) 171-180. doi:10.1016/j.algal.2014.08.001.

[64] M. Nayak, W.I. Suh, B. Lee, Y.K. Chang, Enhanced carbon utilization efficiency and FAME production of Chlorella sp. HS2 through combined supplementation of bicarbonate and carbon dioxide, Energy Convers. Manag. 156 (2018) 45-52. doi:10.1016/J.ENCONMAN.2017.11.002.

[65] E. Günerken, E. D’Hondt, M.H.M. Eppink, L. Garcia-Gonzalez, K. Elst, R.H. Wijffels, Cell disruption for microalgae biorefineries, Biotechnol. Adv. 33 (2015) 243-260. doi:10.1016/J.BIOTECHADV.2015.01.008.

[66] J.J. Milledge, S. Heaven, Methods of energy extraction from microalgal biomass: a review, Rev. Environ. Sci. Bio/Technology. 13 (2014) 301-320. doi:10.1007/s11157-014-9339-1.

[67] RAEng, Sustainability of liquid biofuels, Royal Academy of Engineering, London, 2017.

[68] M. Bekirogullari, J. Pitmman, C. Theodoropoulos, Integrated Computational and Experimental Studies of Microalgal Production of Fuels and Chemicals, in: Comput. Aided Chem. Eng. Vol 37 Eur. Symp. Comput. Process Eng., 2015: pp. 2393-2398.

[69] K. Gao, V. Orr, L. Rehmann, Butanol fermentation from microalgae-derived carbohydrates after ionic liquid extraction, Bioresour. Technol. 206 (2016) 77-85.

doi:10.1016/j.biortech.2016.01.036. 
Table 1. Fermentation titres and yields from glucose-based fermentations subject to different butyric acid, acetic acid, and nitrogen concentration regimes. Stars $(*)$ denote significant differences $\left(\mathbf{p}<0.05^{*}, 0.01 * *\right)$ with respect to Control, as per one-way ANOVA. Results and S.D. are the mean of three biological replicates.

\begin{tabular}{|c|c|c|c|c|c|c|c|}
\hline Label & $\begin{array}{l}\text { Acetone } \\
\text { (A) }\end{array}$ & $\begin{array}{c}\text { Butanol } \\
\text { (B) }\end{array}$ & $\begin{array}{c}\text { Ethanol } \\
\text { (E) }\end{array}$ & $\begin{array}{l}\text { Total } \\
\text { ABE }\end{array}$ & $\begin{array}{l}\text { Substrate (S) } \\
\text { consumption }\end{array}$ & $\underset{\mathbf{Y}_{\mathrm{S} / \mathbf{B}}}{\text { Butanol }}$ & $\begin{array}{r}\mathbf{A B E} \\
\mathbf{Y}_{\mathrm{S}, \mathrm{ABE}}\end{array}$ \\
\hline Control (P2) ${ }^{a}$ & $1.88 \pm 0.03$ & $12.67 \pm 0.30$ & $0.92 \pm 0.05$ & $15.47 \pm 0.47$ & $100 \%$ & $25 \%$ & $31 \%$ \\
\hline $\mathrm{BA}_{0}=2 \mathrm{~g} \mathrm{~L}^{-1}$ & $1.59 \pm 0.44$ & $13.21 \pm 0.70$ & $0.74 \pm 0.24$ & $15.54 \pm 1.71$ & $89 \%$ & $23 \%$ & $28 \%$ \\
\hline $\mathrm{BA}_{0}=4 \mathrm{~g} \mathrm{~L}^{-1}$ & $2.36 \pm 0.11$ & $14.62 \pm 0.28$ & $1.08 \pm 0.07$ & $18.06 \pm 0.58$ & $100 \%$ & $30 \%$ & $37 \%$ \\
\hline $\mathrm{BA}_{0}=8 \mathrm{~g} \mathrm{~L}^{-1}$ & $0.79 \pm 0.08$ & $8.72 \pm 0.43 *$ & $0.41 \pm 0.01$ & $9.93 \pm 0.66$ & $64 \% * *$ & $30 \%$ & $33 \%$ \\
\hline $\mathrm{AA}_{0}=2 \mathrm{~g} \mathrm{~L}^{-1}$ & $1.78 \pm 0.22$ & $11.04 \pm 0.71$ & $0.85 \pm 0.07$ & $13.67 \pm 1.23$ & $99 \%$ & $24 \%$ & $28 \%$ \\
\hline $\mathbf{A A}_{0}=4 \mathrm{~g} \mathrm{~L}^{-1}$ & $2.25 \pm 0.02$ & $11.48 \pm 0.03$ & $0.91 \pm 0.02$ & $14.63 \pm 0.10$ & $100 \%$ & $24 \%$ & $30 \%$ \\
\hline $\mathrm{AA}_{0}=8 \mathrm{~g} \mathrm{~L}^{-1}$ & $2.63 \pm 0.04$ & $12.01 \pm 1.29$ & $1.11 \pm 0.13$ & $15.75 \pm 1.79$ & $100 \%$ & $26 \%$ & $34 \%$ \\
\hline $\mathrm{BA}_{0}, \mathrm{AA}_{0}=4 \mathrm{~g} \mathrm{~L}^{-1}$ & $2.11 \pm 0.08$ & $12.76 \pm 0.39$ & $0.90 \pm 0.4$ & $15.77 \pm 0.63$ & $93 \%$ & $27 \%$ & $34 \%$ \\
\hline$N_{0}=4 g ~ L^{-1}$ & $2.48 \pm 0.53$ & $11.74 \pm 0.75$ & $1.24 \pm 0.11$ & $15.46 \pm 1.87$ & $100 \%$ & $22 \%$ & $29 \%$ \\
\hline$N_{0}=6 g^{-1}$ & $2.97 \pm 0.06$ & $12.45 \pm 0.43$ & $1.27 \pm 0.43$ & $16.70 \pm 0.59$ & $99 \%$ & $24 \%$ & $32 \%$ \\
\hline
\end{tabular}


Table 2. Regression coefficients of the polynomial models (Eq. 1) for acetone, butanol, and ethanol. Stars denote the statistical significance of the coefficients $(\mathrm{p}<0.05 *, 0.01 * *, 0.001 * * *)$ as per one-way ANOVA.

\begin{tabular}{|c|c|c|c|c|c|c|c|c|c|c|}
\hline \multirow[b]{2}{*}{$\alpha_{i}$} & \multirow[b]{2}{*}{$\begin{array}{c}\text { Factors \& } \\
\text { Interaction }\end{array}$} & \multicolumn{3}{|c|}{ Acetone $\left(R^{2}=0.87\right)$} & \multicolumn{3}{|c|}{ Butanol $\left(R^{2}=0.91\right)$} & \multicolumn{3}{|c|}{ Acetone $\left(R^{2}=0.82\right)$} \\
\hline & & Value & $\begin{array}{l}\text { Mean } \\
\text { S.E. }{ }^{a}\end{array}$ & $\mathbf{p}$ & Value & $\begin{array}{l}\text { Mean } \\
\text { S.E. }\end{array}$ & $\mathbf{p}$ & Value & $\begin{array}{c}\text { Mean } \\
\text { S.E. }\end{array}$ & $\mathbf{p}$ \\
\hline$\alpha_{0}$ & - & 1.212 & 0.070 & - & 11.548 & 0.627 & - & 0.713 & 0.019 & - \\
\hline$\alpha_{1}$ & $X_{1}$, Acetic ac. & 0.152 & 0.569 & $0.000 * * *$ & -0.746 & 12.603 & $0.008 * *$ & 0.00 & 0.0190 & 1.000 \\
\hline$\alpha_{2}$ & $X_{2}$, Butyric ac. & 0.567 & 3.057 & $0.000 * * *$ & 2.218 & 46.299 & $0.000 * * *$ & 0.20 & 0.382 & $0.000 * * *$ \\
\hline$\alpha_{3}$ & $X_{1}^{2}$ & -0.001 & 0.072 & 1.000 & 0.074 & 8.414 & 0.061 & 0.00 & 0.0408 & 0.646 \\
\hline$\alpha_{4}$ & $X_{2}^{2}$ & -0.090 & 2.510 & $0.000 * * *$ & -0.372 & 42.101 & $0.000 * * *$ & -0.03 & 0.366 & $0.000 * * *$ \\
\hline$\alpha_{5}$ & $X_{1} \cdot X_{2}$ & -0.037 & 0.196 & $0.000 * * *$ & -0.008 & 0.634 & 1.000 & -0.01 & 0.028 & 0.980 \\
\hline
\end{tabular}

${ }^{a}$ Mean squared error for all experimental runs, if $a_{i}=0$. 
Table 3. Fatty acid methyl esther (FAME) profiles and biodiesel yield in: microalgal biomass (MB), hydrolysed microalgal biomass (MB$\mathrm{H})$, and fermented microalgal biomass (MB-F).

\begin{tabular}{cccc} 
& \multicolumn{3}{c}{ Distribution (\% of FAME) } \\
\cline { 2 - 4 } FAME & MB & MB-H & MB-F \\
\hline C12:0 & 0 & 0.1 & 0.1 \\
C14:0 & 0.8 & 0.7 & 1 \\
C16:0 & 24 & 22.1 & 19.5 \\
C16:1 & 1.9 & 3 & 3.2 \\
C16:3 & 1.2 & 1.6 & 2 \\
C18:0 & 0.9 & 1.7 & 1.4 \\
C18:1 & 5.2 & 9.8 & 4.1 \\
C18:2 & 23.5 & 26.2 & 28.2 \\
C18:3 & 15.4 & 16 & 17 \\
C20:4 & 21.6 & 18.1 & 13.1 \\
C20:5 & 0.5 & 0 & 7.7 \\
C22:0 & 4.9 & 0 & 2 \\
C24:0 & 0.2 & 0.4 & 0.3 \\
Saturated FA & 0 & 0.3 & 0.3 \\
Monounsaturated FA & 30.2 & 33.4 & 25.3 \\
Polyunsaturated FA & 25.4 & 29.2 & 31.4 \\
\hline FAME (mg/g CDW) & 94.5 & 37.4 & 43.2 \\
Biodiesel (FAME) yield (\%) ${ }^{a}$ & 5.82 & 38.2 & 32.9 \\
\hline${ }^{a}$ as computed by Eq.4 & & 24.16 & 20.8 \\
\hline
\end{tabular}

${ }^{a}$ as computed by Eq.4 
Table 4. Comparison between different algal pre-treatments and corresponding biobutanol yields and biodiesel (FAME) contents.

\begin{tabular}{|c|c|c|c|c|c|c|}
\hline Microalgae & $\begin{array}{c}\text { Biomass } \\
\text { Pre-treatment }\end{array}$ & $\begin{array}{c}\text { ABE } \\
\text { substrate }\end{array}$ & $\begin{array}{c}\text { Butanol } \\
\mathrm{g} \mathrm{L}^{-1}(\%)\end{array}$ & $\begin{array}{c}\text { Lipid extraction } \\
\text { solvent }\end{array}$ & $\begin{array}{c}\text { Biodiesel } \\
\left(\%^{a}\right) \\
\end{array}$ & Reference \\
\hline C. reinhardtii & $\begin{array}{l}\text { Pulverised }+ \text { Freeze- } \\
\text { dried }(\mathrm{P}+\mathrm{F})\end{array}$ & - & - & Hexane $\left(155^{\circ} \mathrm{C}, 2 \mathrm{~h}\right)$ & 0.92 & \multirow{3}{*}{ This work } \\
\hline C. reinhardtii & $\mathrm{P}+\mathrm{F}+$ Sterilised $(\mathrm{S})$ & $\operatorname{Algae}(1 \% \mathrm{w} / \mathrm{v})$ & $1.031(10.31)$ & Hexane $\left(155^{\circ} \mathrm{C}, 2 \mathrm{~h}\right)$ & 3.29 & \\
\hline C. reinhardtii & $\begin{array}{c}\mathrm{P}+\mathrm{F}+\mathrm{S}+ \\
\text { Hydrolysed (acid) }\end{array}$ & $\begin{array}{c}\text { Algal hydrolysate } \\
\left(S_{o}=8.6 \mathrm{~g} \mathrm{~L}^{-1} \text { glucose }\right)\end{array}$ & $0.89(10.07)$ & Hexane $\left(155^{\circ} \mathrm{C}, 2 \mathrm{~h}\right)$ & 3.82 & \\
\hline Mixed culture & Lyophylised & $x_{1}$ & - & $\begin{array}{l}\text { Chloroform:Methanol }(2: 1) \\
\left(4{ }^{\circ} \mathrm{C} \text {, overnight }\right)\end{array}$ & 1.22 & \multirow{2}{*}{$\begin{array}{l}\text { Velasquez-Orta } \\
\text { et al. (2014) }\end{array}$} \\
\hline Mixed culture & $\begin{array}{l}\text { Ozoflotation } \\
\text { Lyophylised }\end{array}$ & - & - & $\begin{array}{l}\text { Chloroform:Methanol }(2: 1) \\
\left(4^{\circ} \mathrm{C} \text {, overnight }\right)\end{array}$ & 3.23 & \\
\hline $\begin{array}{l}\text { Scenedesmus } \\
\text { dimorphus }\end{array}$ & Boiled (isopropanol) & - & - & $\begin{array}{l}\text { Chloroform:Methanol (2:1) } \\
\text { (room temperature, } 2 \mathrm{~min} \text { ) }\end{array}$ & $\sim 6.5$ & \multirow{4}{*}{$\begin{array}{l}\text { Lage and Gentili, } \\
\qquad(2018)\end{array}$} \\
\hline Scenedesmus dimorphus & Frozen & - & - & $\begin{array}{l}\text { Chloroform:Methanol (2:1) } \\
\text { (room temperature, } 2 \mathrm{~min} \text { ) }\end{array}$ & $\sim 10$ & \\
\hline Scenedesmus dimorphus & Oven-dried & - & - & $\begin{array}{l}\text { Chloroform:Methanol (2:1) } \\
\text { (room temperature, } 2 \mathrm{~min} \text { ) }\end{array}$ & $\sim 10$ & \\
\hline Scenedesmus dimorphus & Freeze-dried & - & - & $\begin{array}{l}\text { Chloroform:Methanol (2:1) } \\
\text { (room temperature, } 2 \mathrm{~min} \text { ) }\end{array}$ & $\sim 5$ & \\
\hline Mixed culture & Hydrolysed (acid) & Treated algae $(10 \% \mathrm{w} / \mathrm{v})$ & $2.26(10.10)$ & - & - & \multirow{2}{*}{ Ellis et al. (2012) } \\
\hline Mixed culture & N/A & Un-treated algae (10 \%) & $0.52(17.30)$ & - & - & \\
\hline Chlorella vulgaris & Freeze-dried & Lipid extracted* algae (8\% w/v) & $6.63(23)$ & \multirow{2}{*}{$\begin{array}{l}\text { Hexane:2-propanol }(3: 2) \\
\text { (room temperature, } 16 \mathrm{~h} \text { ) }\end{array}$} & 13.80 & \multirow{4}{*}{ Gao et al. (2016) } \\
\hline Chlorella vulgaris & Freeze-dried & $\begin{array}{l}\text { Lipid extracted* algal hydrolysate } \\
\qquad\left(S_{o}=28.88 \mathrm{~g} \mathrm{~L}^{-1} \text { glucose }\right)\end{array}$ & $0.44(4)$ & & 13.80 & \\
\hline Chlorella vulgaris & Freeze-dried & Lipid extracted* algae $(8 \%$ w/v) & $4.99(15)$ & \multirow{2}{*}{$\begin{array}{c}\text { Ionic liquid } \\
{\left[\mathrm{C}_{2} \text { mim }\right][\text { EtOH }]} \\
\text { (room temperature, } 2 \mathrm{~h} \text { ) }\end{array}$} & 13.80 & \\
\hline Chlorella vulgaris & Freeze-dried & $\begin{array}{l}\text { Lipid extracted* algal hydrolysate } \\
\qquad\left(S_{o}=36.45 \mathrm{~g} \mathrm{~L}^{-1} \text { glucose }\right)\end{array}$ & $5.34(15)$ & & 13.80 & \\
\hline
\end{tabular}

${ }^{a}$ for biobutanol: \% refers to $g g^{-1} c d w(M B)$, or $g g^{-1}$ glucose; for biodiesel: \% refers to $g g^{-1} c d w(M B, M B-H, M B-F)$. Ash content in cdw was not quantified. 
FIGURE 1

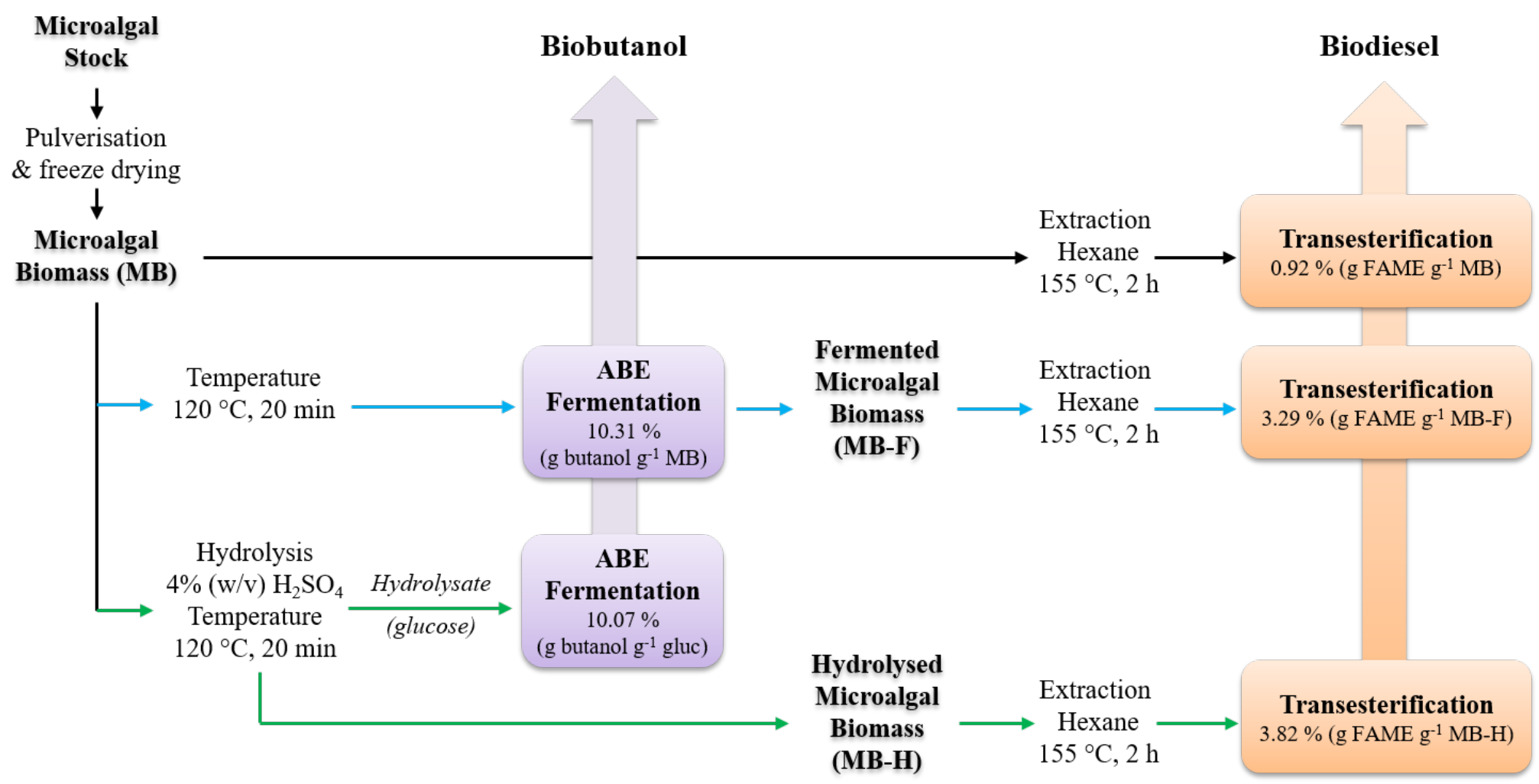

Figure 1. Schematic diagram of the biofuel production routes evaluated in this case-study along with the corresponding microalgal biomass pre-treatment steps and yields. 


\section{FIGURE 2}
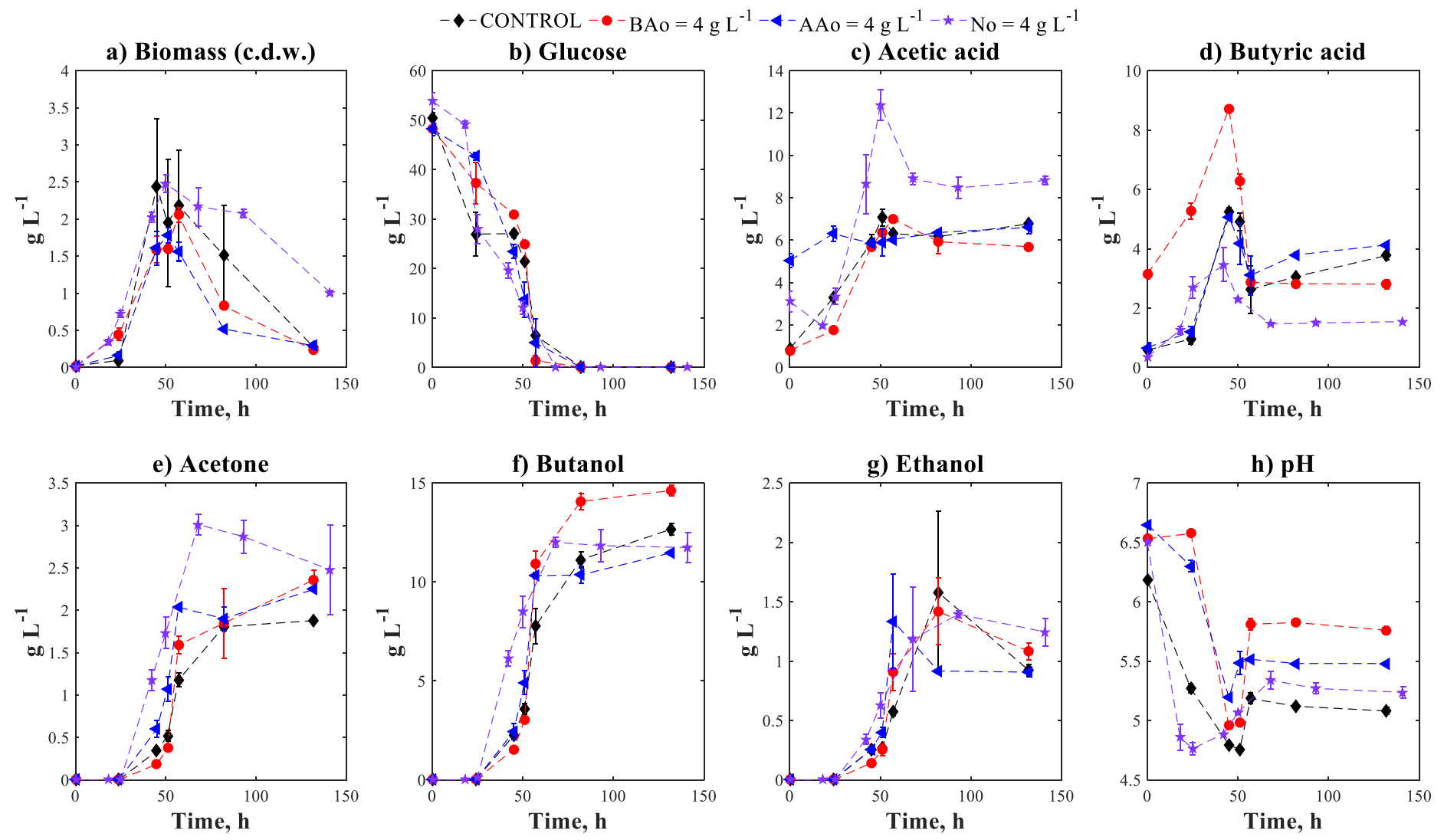

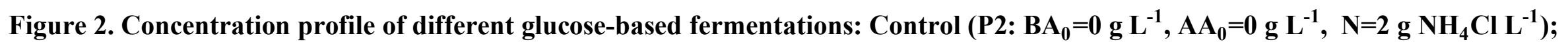
$B A_{0}=4 \mathrm{~g} \mathrm{~L}^{-1}$ (with $\mathrm{AA}_{0}=0 \mathrm{~g} \mathrm{~L}^{-1}$ and $\mathrm{N}=2 \mathrm{~g} \mathrm{NH}_{4} \mathrm{Cl} \mathrm{L}^{-1}$ ); $A A_{0}=4 \mathrm{~g} \mathrm{~L}^{-1}$ (with $\mathrm{BA}_{0}=0 \mathrm{~g} \mathrm{~L}^{-1}$, and N=2 $\mathrm{g} \mathrm{NH}_{4} \mathrm{Cl} \mathrm{L}^{-1}$ ), and N=4 $\mathrm{g} \mathrm{NH}_{4} \mathrm{Cl}$ $\mathrm{L}^{-1}$ (with $\mathrm{BA}_{0}=0 \mathrm{~g} \mathrm{~L}^{-1}$ and $\mathrm{AA}_{0}=0 \mathrm{~g} \mathrm{~L}^{-1}$ ). Results and S.D. are the mean of three biological replicates. 


\section{FIGURE 3}

a) Acetone

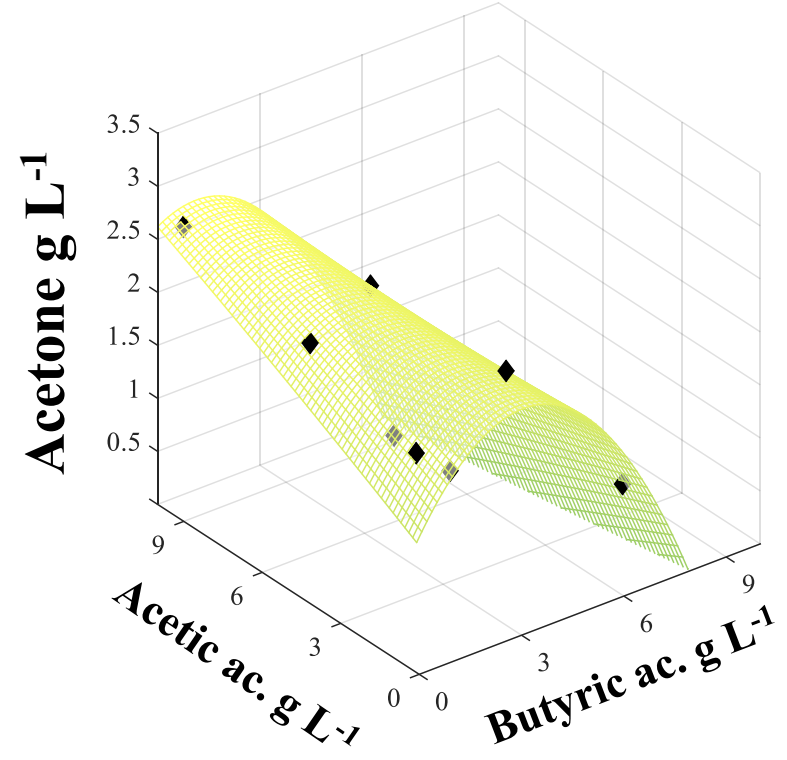

b) Butanol

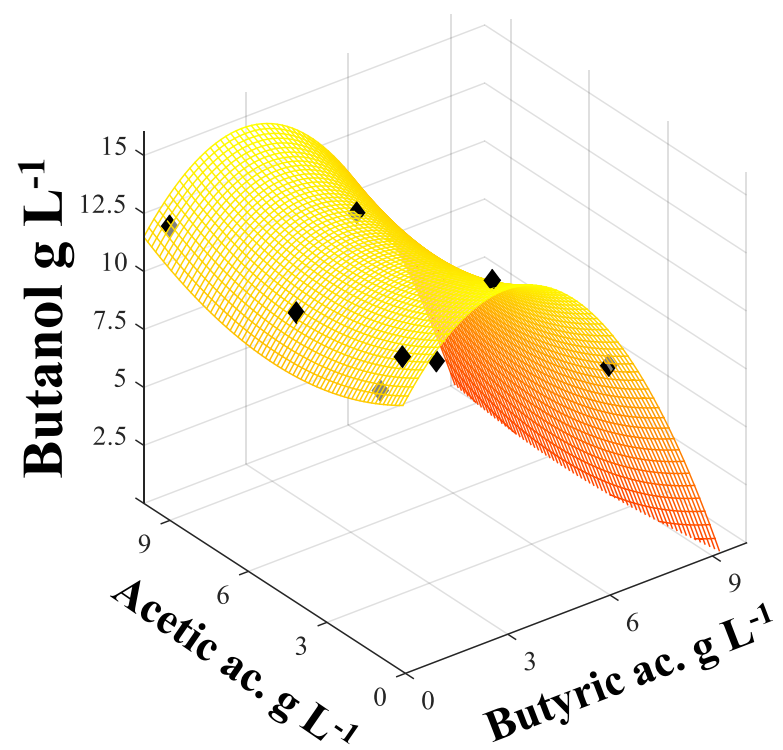

c) Ethanol

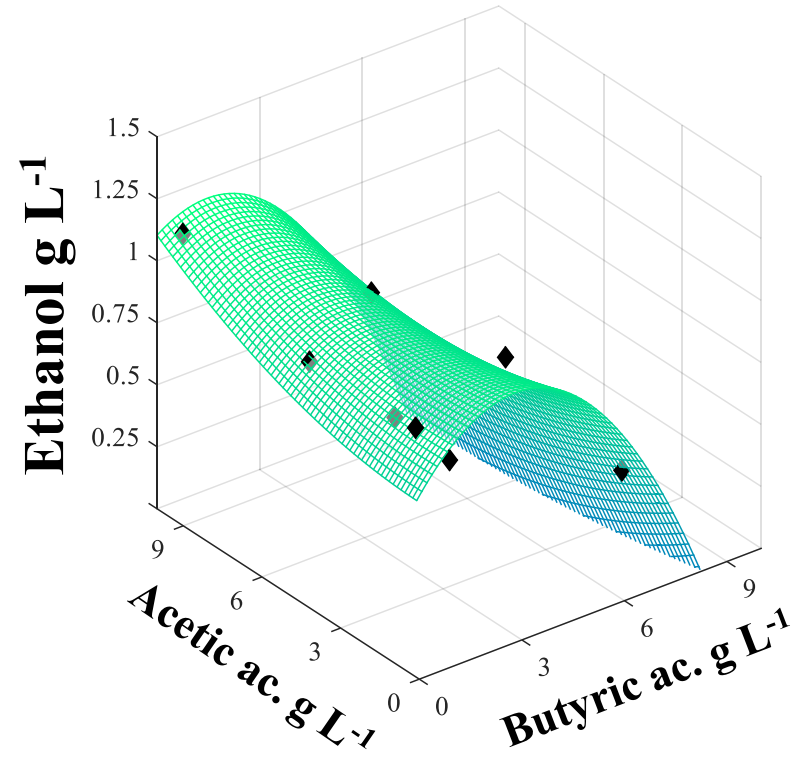

Figure 3. Response surface plots for acetone, butanol, and ethanol, showing the effects of initial acetic acid and butyric acid medium concentrations. Black points are experimental data (mean) obtained under the corresponding medium concentrations. 


\section{FIGURE 4}
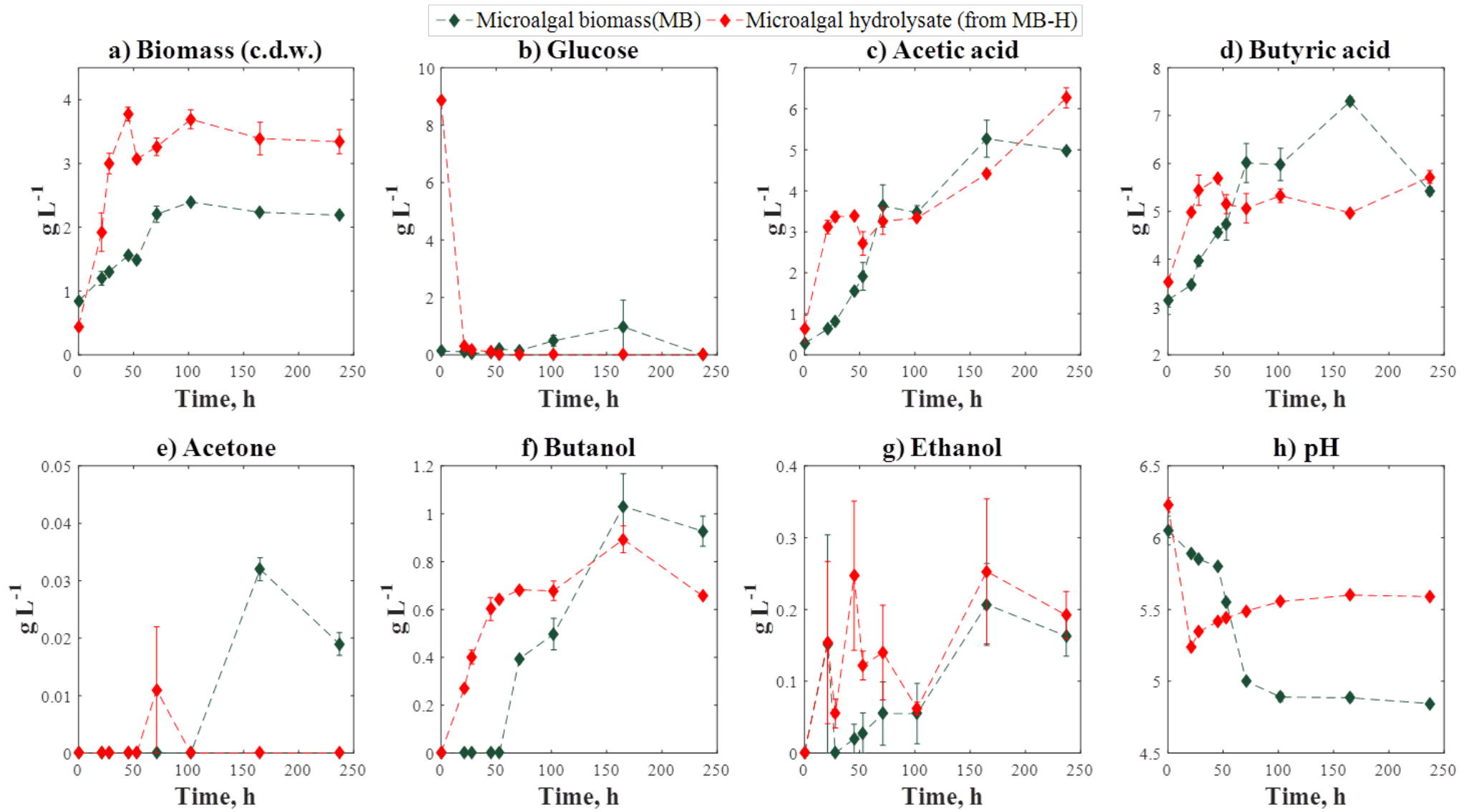

Figure 4. Concentration time-profile of fermentations using microalgal biomass (MB), and microalgal hydrolysate (derived from hydrolysed microalgal biomass, i.e. MB-H). Results and S.D. are the mean of two biological replicates. 


\section{FIGURE 5}

a) Saponifiable Lipids (FAMEs)

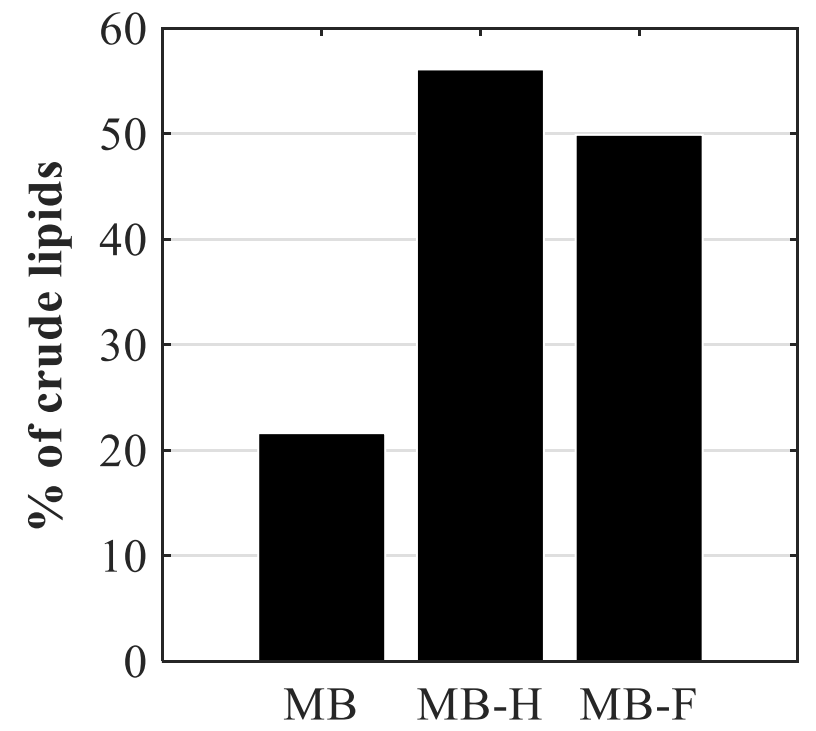

b) FAME composition

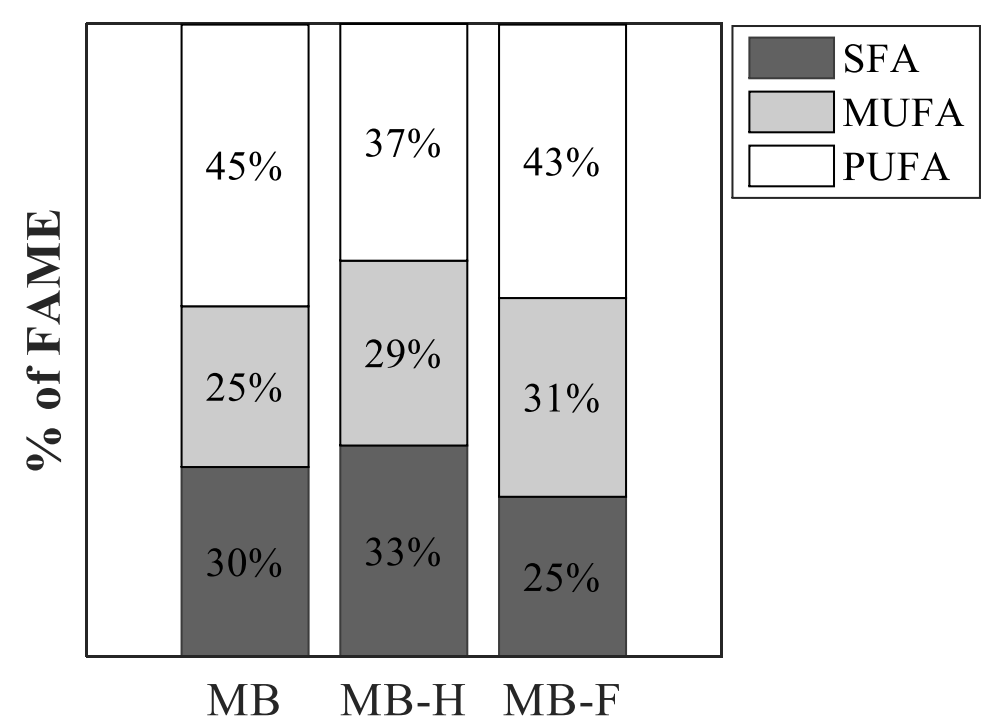

Figure 5. a) Saponifiable (FAME ) lipid content, and b) FAME composition of: microalgal biomass (MB), hydrolysed microalgal biomass (MB-H), and fermented microalgal biomass (MB-F). [SFA, saturated fatty acids; MUFA, monounsaturated fatty acids; PUFA, polyunsaturated fatty acids]. 